\title{
Mediterranean limnology: current status, gaps and the future
}

\author{
Miguel ALVAREZ COBELAS*, Carmen ROJO ${ }^{1)}$ and David G. ANGELER ${ }^{2)}$ \\ CSIC-Centro de Ciencias Medioambientales, Serrano 115 dpdo., E-28006 Madrid, Spain \\ ${ }^{1)}$ Instituto Cavanilles de Biodiversidad y Biología Evolutiva, Univ. Valencia, Apartat Oficial 2085, Paterna, E-46071 Valencia, Spain \\ ${ }^{2)}$ Instituto de Ciencias Ambientales, Univ. Castilla-La Mancha, Avenida Carlos III s/n, E-45071 Toledo, Spain \\ *e-mail corresponding author: malvarez@ccma.csic.es
}

\begin{abstract}
The current ecosystem paradigm in limnology is represented by the cold temperate, stratifying lake and the single-channelled river. However, the variety of inland water ecosystems is much higher, and so is the ecological complexity of many of them. Most Mediterranean limnosystems are quite distinct from the contemporary limnological paradigm. This overview will deal with the striking and exciting differences between Mediterranean and other temperate limnosystems. For example, most are very small, their catchment area is much larger than their size, and they experience both a longer vegetation period and a strong seasonality in water supply which occurs outside the hot season, often from groundwater sources. In addition, we encourage research on the often poorly known limnological processes taking place in Mediterranean regions by pointing at insufficiently covered research fields. Furthermore, competition for water among different users, arising from population increase in fertile and/or tourist areas, is certainly limiting the ability of many Mediterranean limnosystems to survive at present and in the near future, particularly in the face of the harsher environmental conditions that climatic change is triggering. A new paradigm on Mediterranean limnology is thus necessary. This will enable us to predict and mitigate more accurately the unstoppable effects of man-made change in these beautiful and still largely ignored ecosystems.
\end{abstract}

Key words: state-of-the-art, cold temperate and tropical limnosystems, climate change, mitigation measures

\author{
Mite letargo d'acque \\ [Lukewarm lethargy of water] \\ Salvatore Quasimodo \\ (Italian poet and Nobel laureate for Literature 1959)
}

\section{INTRODUCTION}

Monsieur Jourdain's character of Molière was amazed whenever he spoke prose (Act II, Scene 4, 1670). So are many of the limnologists when they deal with aquatic ecosystems. This metaphor reflects especially what Mediterranean limnologists feel when they try to unravel the many current enigmas around the ecology of the aquatic world in Mediterranean areas, and try fitting their results into current limnological paradigms. This is no easy task, however, because Mediterranean limnology as a science historically lags behind the traditional limnology of temperate lake and river ecosystems. As a consequence, the application of contemporary intellectual frames to Mediterranean limnology is likely not very appropriate (AlvarezCobelas et al. 1992a; Harris 1999; and a large etc.). Furthermore, we are beginning to see that Mediterranean limnology does not meld well with many concepts of temperate limnology, as the many "exceptions to the rule" statements in discussions of scientific papers by Mediterranean limnologists highlight (Angeler \& Rodrigo 2004; Ortega-Mayagoitia et al. 2002a). It is time therefore to appreciate that Mediterranean limnology cannot be forced ad hoc in current conceptual frameworks. We must begin to create a Mediterranean limnology paradigm, thereby widening the general paradigm of this science. This short, unavoidable subjective, overview is a first step in this direction.

\section{BRIEF HISTORY AND CURRENT STATUS}

First surveys of Mediterranean freshwater ecosystems can be dated back to Forel's (1889) studies in Lombardy lakes. Some scattered efforts were carried out in the first third of the $20^{\text {th }}$ Century (Hutchinson et al. 1932; Stanković 1931), but only after World War II a strong impulse has been given by Italians at the Pallanza's Istituto Italiano di Idrobiologia (Bertoni \& De Bernardi 1997), the earlier Yugoslavian limnologists (Stanković, Ocevski) and the solitary figure of Margalef in Spain (Ros 1991) to be followed later by the outburst and strong development of Australian, Israeli and South-African limnology.

The wealth of Mediterranean limnology is reflected by the words which different languages of Mediterranean cultures use when referring to Mediterranean aquatic ecosystems. A non-exhaustive list is shown in table 1 . The reader will notice that we intentionally omitted words such as "lake", "river", "stream" and their translations because we wish to emphasize the existence of other, often ignored limnosystems (e.g., temporary pools and streams, etc.) that are worthwhile for research 
Tab. 1. Mediterranean lexikon on limnosystems. Words and translations are from González-Bernáldez (1992), Luigi Naselli Flores (Univ. Palermo, Italy), Lourdes Domingo (School of Modern Languages, Murcia, Spain), Said Messari, Maria Leitao (Bi-Eau, Angers, France), Radovan Erben (Univ. Zagreb, Croatia) and Rose Angeler (Grafenbach, Austria). In bracketts, the language of each word is given. As an Italian motto says, traduttore: traditore [translator: traitor], so we assume responsibility for any mistake when attempting word equivalence. The languages are the following: afr $=$ Afrikaan; alb = Albanian; ar $=$ Arabic; au = native Australian; ber = Bereber; cat = Catalan; cro = Croatian; en = English; fr = French; gr = Greek; ir = Irish; it = Italian; $\mathrm{mt}=\mathrm{Maltese} ; \mathrm{pt}=$ Portuguese; $\mathrm{sa}=$ Sardo; $\mathrm{sic}=$ Sicilian; $\mathrm{sp}=$ Spanish; tu $=$ Turkish .

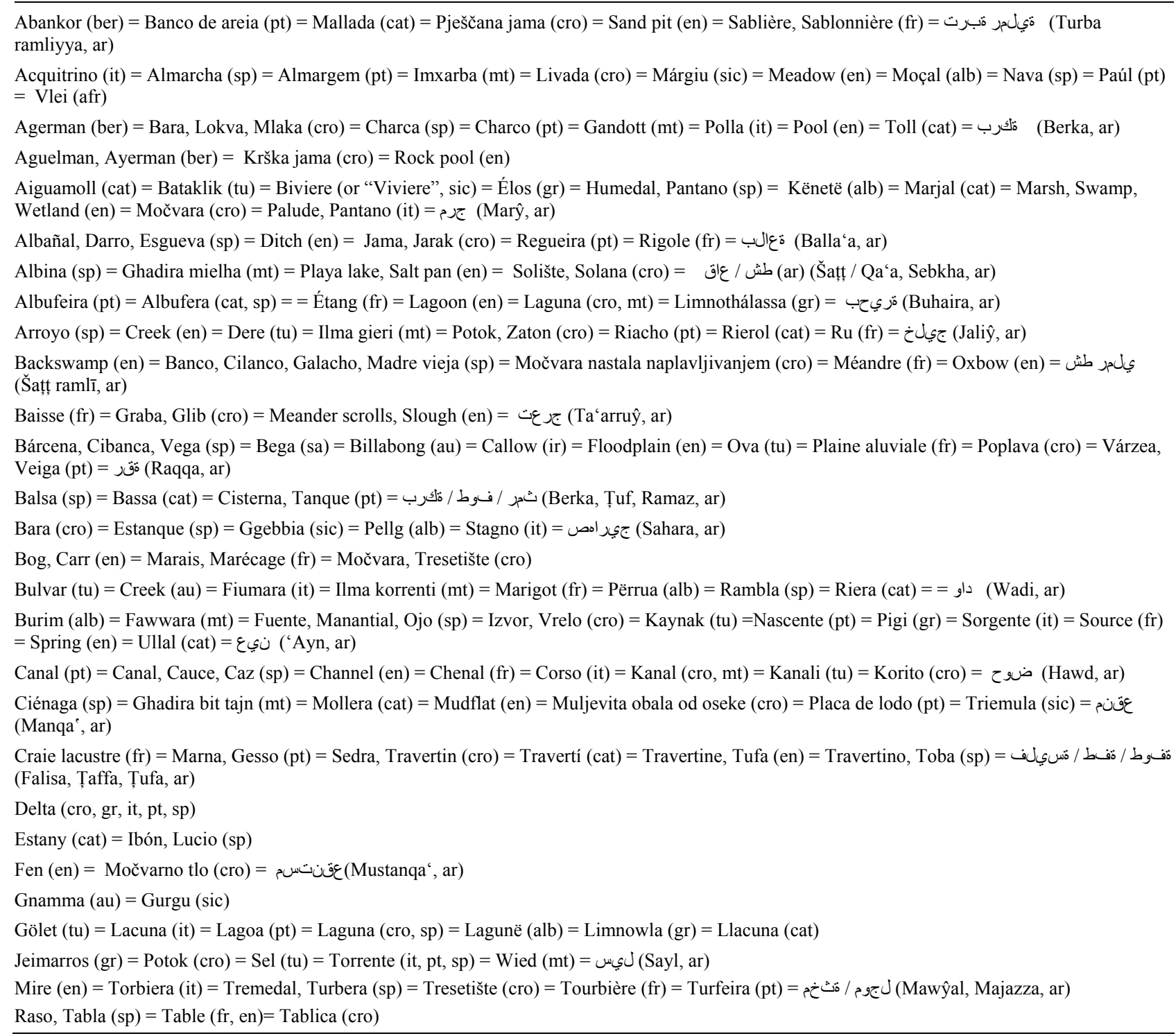

because of their enormous scientific and social interest. So in addition to lakes and rivers, which have been studied exhaustively in cold temperate climates, there are other, often more abundant, ecosystem types in Mediterranean regions of the world, which make the aquatic habitat more diverse.

The Mediterranean climate is experienced in the Mediterranean basin (sensu stricto), the south-western part of South Africa, Southern California, the southwestern and southern part of Australia and Central Chile (Bolle 2003). It is not easy to place boundaries of Mediterranean climate in the Mediterranean basin (Jeftic et al. 1992; Bolle 2003). As a compromise for France, we have chosen to use river catchments draining to the Mediterranean Sea as the northern boundary (Birot 1970); so the Rhône and the minor watersheds of the Gulf of Lion are included in the Mediterranean limnological area. Mediterranean climate is characterized by a strong seasonality of rainfall and air temperature (Fig. 1), which are out of phase. Rainfall occurs mostly in spring and autumn (Bolle 2003). Also, the annual rainfall-to-potential evapotranspiration ratio ranges from 0.12 to 1 , resulting in water shortages and droughts in many Mediterranean landscapes for considerable time of the year.

This section will be devoted to outline some features that make Mediterranean inland waters different from cold temperate and tropical limnosystems. We have 


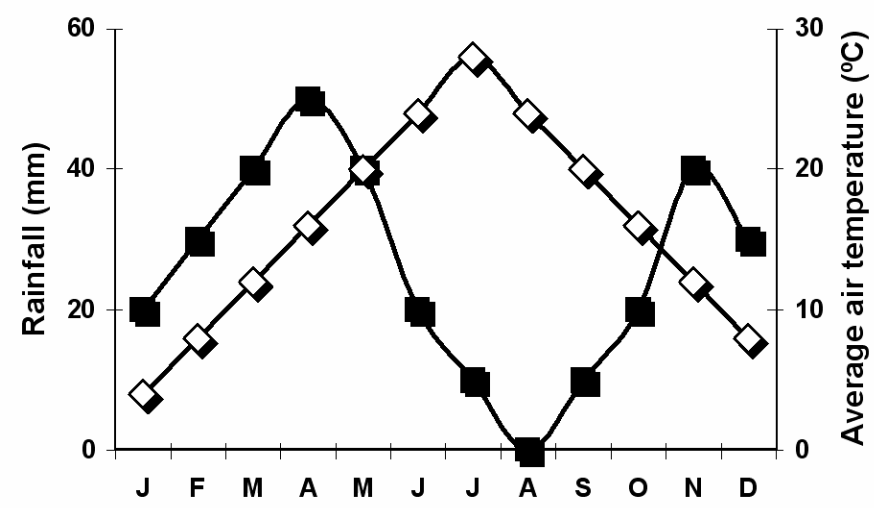

Fig. 1. Average air temperature and rainfall in 2003 in Ruidera Lakes (Central Spain). Data source: Lagunas de Ruidera Natural Park.

STREAMS
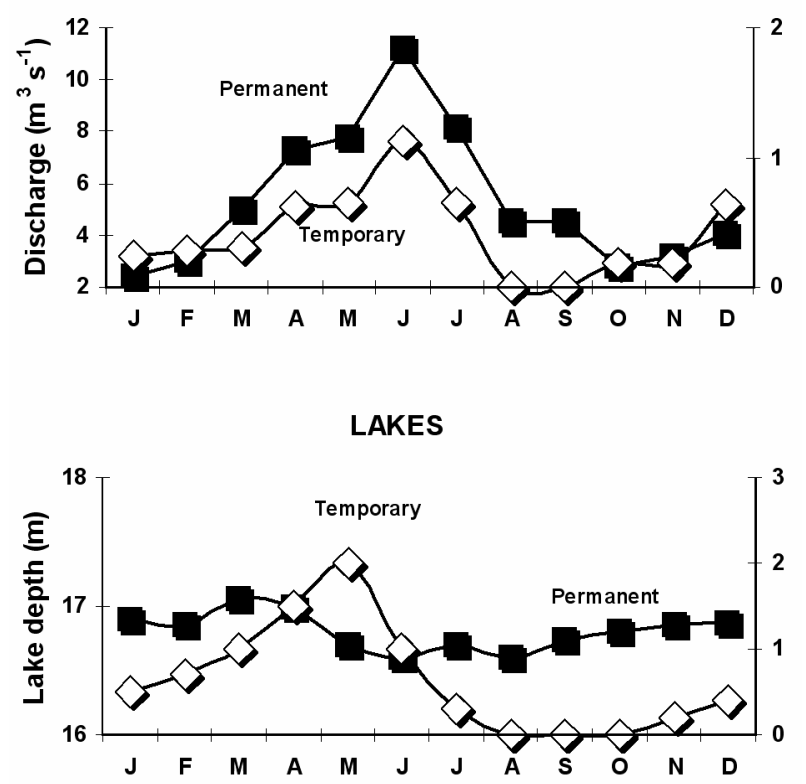

Fig. 2. Upper pannel. Seasonal discharge in a permanent (Pinilla River, left ordinate) and a temporary (Upper Gigüela River, right ordinate) stream in Central Spain. Data sources: Alvarez-Cobelas (unpublished data) and Guadiana Water Authority. Lower pannel. Seasonal lake levels in a permanent (Lake del Rey, left ordinate) and a temporary lake (Manjavacas Lake, right ordinate) in Central Spain. Data sources: Lagunas de Ruidera Natural Park and Alvarez-Cobelas (unpublished data).

selected only a few examples for which we are beginning to understand underlying mechanisms and processes of functioning. Obviously (read hopefully) the range of examples can be widened with the increase of our understanding of Mediterranean ecology in the future.

The strong seasonality of rainfall has important implications for water availability in Mediterranean limnosystems. As data from Central Spanish streams and lakes show (Fig. 2), a delayed response to rainfall patterns is evident in water discharge in streams and water levels in lakes. Depending on the availability of water and biophysical settings, Mediterranean aquatic ecosystems occur on a permanence gradient, and include ephemeral to permanent water bodies (Boulton \& Brock 1999).

Another key feature for Mediterranean limnosystems is that of landscape structure which can be useful for regional studies (Kalff 1991). Many limnological processes have been shown to depend partly on landscape features, an index of which is extension. Figure 3 shows the striking difference between the catchment:lake ratio for cold temperate and Mediterranean lentic systems. The data for temperate ecosystems are taken from the book by Kalff (2002), whereas those from the Mediterranean have been gathered from the extensive study on Sicilian reservoirs by Calvo et al. (1993). The regional differences are 


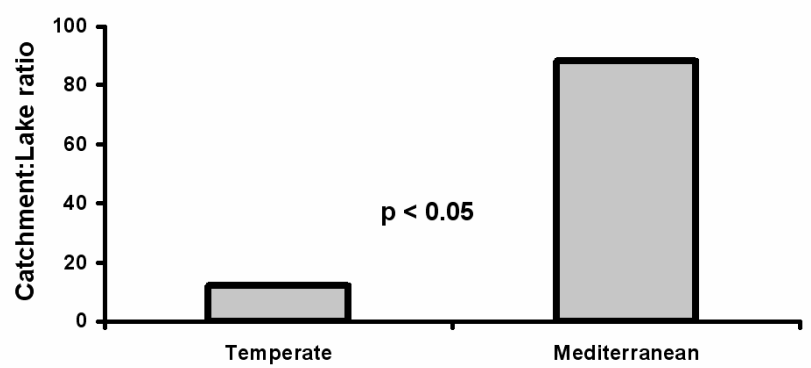

Fig. 3. Comparison of catchment:lake area ratios in cold temperate and Mediterranean limnosystems. Data sources: Kalff (2002, table 9-3) and Calvo et al. (1993). A Mann-Whitney test was performed to check the otherwise easily seen difference between both data sets.

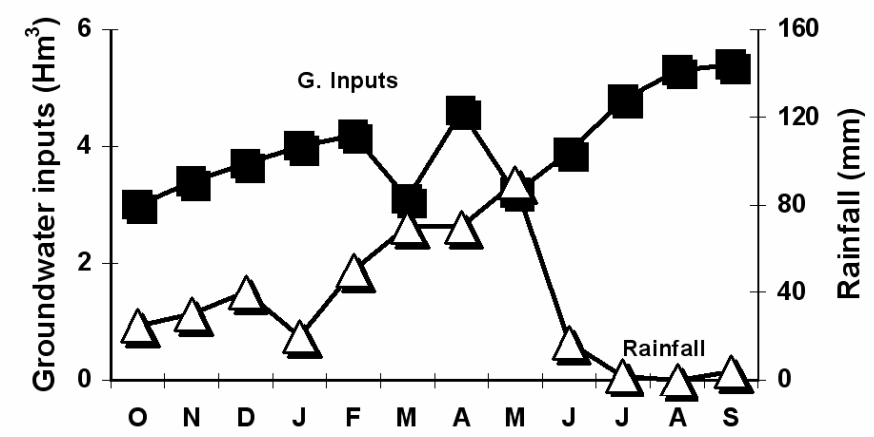

Fig. 4. Groundwater inputs to and rainfall over Lake La Colgada (Lagunas de Ruidera Natural Park) in the hydrological year 20032004. Data sources: Montero (unpublished data) and Lagunas de Ruidera Natural Park.

appreciable at one glance. Mediterranean limnosystems should experience stronger catchment effects than those in most cold temperate and tropical climates. Many Mediterranean studies acknowledge the influence of regional landscape characteristics but they have been scarcely used to explain local ecological phenomena. Studies such as those by Likens (1985) or Johnson et al. (1997) for other climatic regions will need to be designed for Mediterranean areas.

Furthermore, many Mediterranean environments are shallow, thus increasing the importance of emergent and submerged plants and the benthic-pelagic interactions for overall limnological functioning (Moss et al. 2004). Processes related to vegetation and the benthic-pelagic coupling should more importantly regulate ecosystem processes in the Mediterranean compared with cold temperate limnosystems. However, these phenomena are only beginning to be explored in Mediterranean aquatic ecology.

In Mediterranean areas groundwater hydrology is as important as surface hydrology for the persistence and functioning of aquatic ecosystems. In many stagnant and flowing Mediterranean limnosystems, water availability depends a great deal on groundwater discharge, which is either lagged from rainfall seasonality or lacks any seasonality because it depends in turn upon the hydrogeologic features of the subterranean aquifer. In Central Spanish Ruidera lakes, despite a seasonal rainfall, the discharge of groundwater to the lakes is not seasonal at all (Fig. 4). In addition to water availability, groundwater can be a source of nutrients to limnosystems, as is often the case in agriculturally-used areas (Alvarez-Cobelas et al. 2004; Lamontagne 2002).

Another significant Mediterranean climate effect on limnosystems is the number of sunny hours in the year, which affects the length of the vegetative season positively and hence the variability of annual phytoplankton biomass. Figure 5 represents the ratio between maximal phytoplankton and average phytoplankton biomass in stratifying lakes of tropical, cold temperate and Mediterranean areas. Data for tropical and cold temperate lakes are reported in Lewis (1990), data for Mediterranean systems have been gathered from Greek, Italian and Spanish lakes. Mediterranean and tropical lakes have higher ratios than cold temperate lakes, which imply a response to the longer growing season. Mediterranean systems, however, show higher variability of that ratio than cold temperate and tropical lakes. Unfortunately the underlying mechanisms of this variability cannot be explained accurately at the present moment.

Chlorophyll responses to total phosphorus, a fundamental topic in applied limnology, also appear to be functionally distinct between temperate and Mediterranean areas, as these relationships show. 


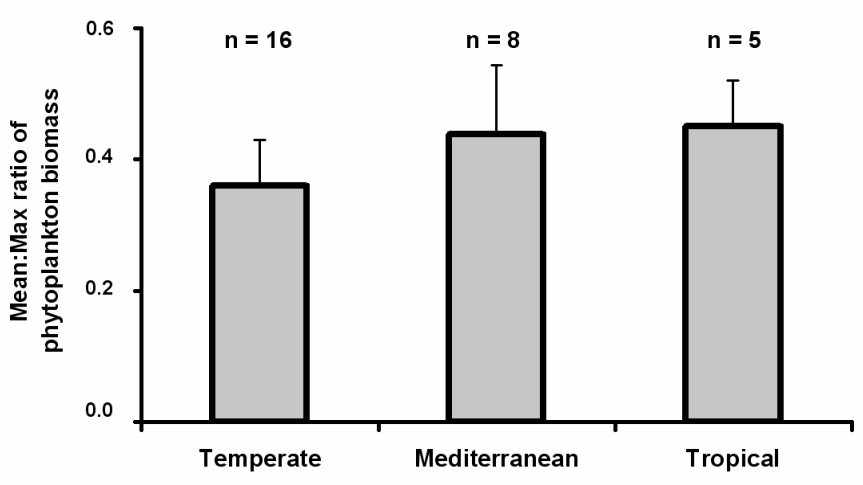

Fig. 5. Mean-to-max ratio of seasonal phytoplankton biomass in cold temperate, tropical and Mediterranean lakes. Only data sets with monthly sampling throughout an entire year have been used. Data sources: Alvarez-Cobelas (unpublished data, El Lakes Campillo and Las Madres, Spain), Alvarez-Cobelas et al. (1992, El Porcal Lake, Spain), Lewis (1990), Moustaka-Gouni (1993, Lake Volvi, Greece), Moustaka-Gouni \& Nikolaidis (1990, Lake Vegoritis, Greece), Naselli-Flores \& Barone (1998, Lakes Arancio and Rosamarina, Italy) and Planas (1973, Lake Banyoles, Spain).

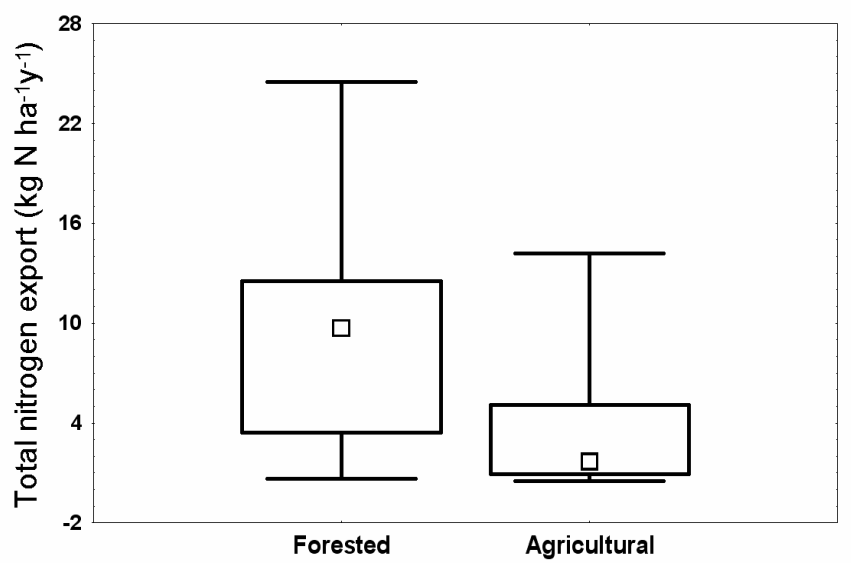

Fig. 6. Nitrogen export in forested and non-forested catchments of Alto Guadiana basin (Central Spain) in 2003. Data source: Alvarez-Cobelas (unpublished data).

Chl- $a_{\mathrm{MAX}}=0.74 \mathrm{TP}_{\mathrm{AVE}}{ }^{0.97} \mathrm{r}=0.91 ; \mathrm{n}=20$

(OECD 1982, Shallow lakes and reservoirs Project)

$$
\text { Chl- } a_{\mathrm{MAX}}=0.45 \mathrm{TP}_{\mathrm{AVE}}{ }^{0.64} \mathrm{r}=0.62 ; \mathrm{n}=68
$$

(Spanish reservoirs, Alvarez-Cobelas, unpublished)

Chl- $a_{\text {MAX }}=0.54 \mathrm{TP}_{\text {LOADING }}{ }^{0.72} \mathrm{r}=0.87 \mathrm{n}=20$

(OECD 1982, Shallow Lakes and reservoirs Project)

Chl- $a_{\text {MAX }}=1.43 \mathrm{TP}_{\text {LOADING }}{ }^{0.40} \mathrm{r}=0.65 \mathrm{n}=25$

(Spanish reservoirs, Ortiz-Casas \& Peña 1984)

where Chl- $a_{\mathrm{MAX}}$ is averaged epilimnetic chlorophyll " $a$ " during stratification, $\mathrm{TP}_{\mathrm{AVE}}$ is averaged total phosphorus in the water-column at late mixing, and $\mathrm{TP}_{\text {LOADING }}$ is $\mathrm{TP}_{\mathrm{AVE}}$ corrected for the Vollenweider \& Kerekes' loading term (OECD 1982). In a straightforward way, the epilimnetic chlorophyll " $a$ " in summer has a flatter response to average phosphorus content of the water column in Spanish reservoirs than in the OECD shallow lakes and reservoir study. Also, the explained variability is lower (around 40\%) suggesting that other variables than phosphorus more importantly mediate chlorophyll variability in Mediterranean limnosystems compared with cold temperate lakes and reservoirs. The same happens if we consider the classical loading term of $\mathrm{P}$ studies which in the case of Mediterranean aquatic ecosystems, may be influenced by the smaller size of catchments (see above).

In a cross regional comparison, perplexity can also arise when we focus on nutrient metabolism in streams. Unfortunately, there are few studies on this topic in Mediterranean areas as compared with those in temperate zones, and this is a gap to which we will refer later. For now, our own data show that forest catchments appear to export more nitrogen than agricultural areas in Central Spanish streams (Fig. 6), while the converse happens in cold temperate streams (e.g. Mayer et al. 2002). Concerning phosphorus, however, no statistically difference has been found between agricultural and forested catchments in our streams. This is another topic that deserves a closer scrutiny in view of the increasing concern on nitrogen effects worldwide (Vitousek et al. 1997).

Differences between cold temperate and Mediterranean limnosystems can also be found in 

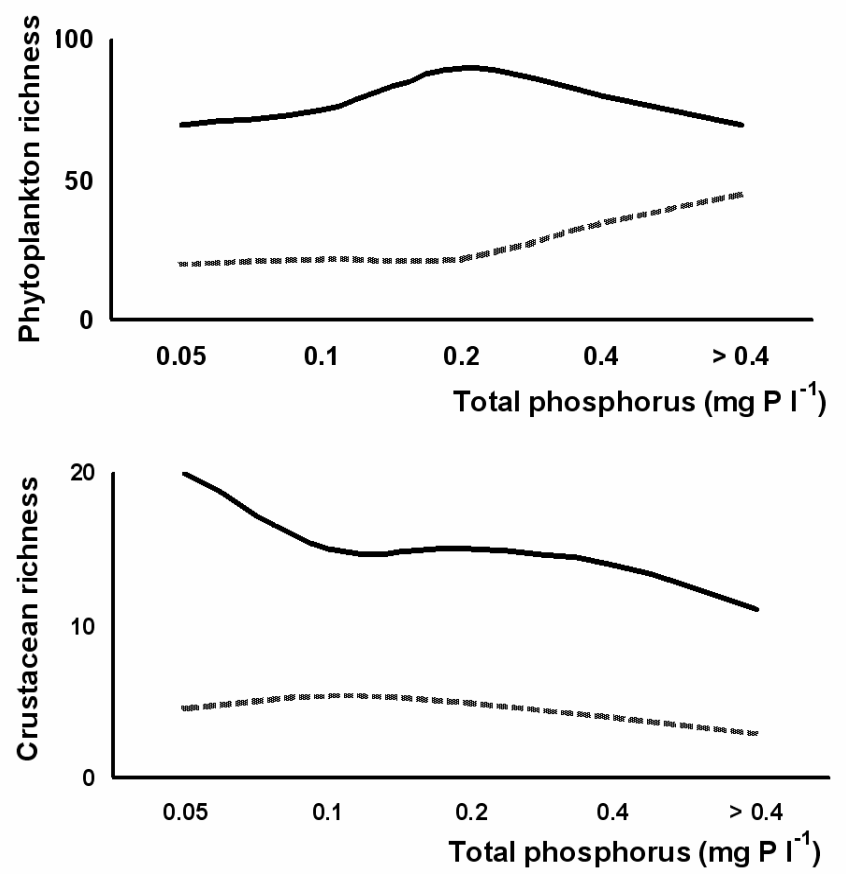

Fig. 7. Patterns of planktonic species richness $v s$ total phosphorus in Spain (dashed line) as compared with those of Danish lakes (solid line). Data sources: Spanish phytoplankton (Alvarez-Cobelas, unpublished data), Spanish crustaceans (Alonso 1998), Danish plots (adapted from Jeppesen et al. 2000).

species richness, the highest concern of taxonomicallyoriented limnologists. If we plot the trend of phytoplankton and crustacean richness along a phosphorus gradient in Danish lakes (Jeppesen et al. 2000), phytoplankton richness peaks at intermediate phosphorus concentrations, but Crustaceans do so in oligotrophic sites (Fig. 7). In Spain, however, phytoplankton richness correlates positively with phosphorus and Crustaceans peak at intermediate concentrations of phosphorus. It seems that the threshold of highest richness at intermediate nutrient concentrations (Connell 1978; Carney \& Elser 1990) was shifted towards higher TP values in Mediterranean limnosystems, but again no sound explanation can be advanced yet.

In the last thirty years there has been a growing interest regarding limnetic food webs, often linked to biomanipulation as a tool for improving water quality. Some useful concepts, such as the trophic cascade (Carpenter \& Kitchell 1993) or the alternative stable states (Scheffer 1998), have emerged based on studies in cold temperate climates. Though useful for Mediterranean areas, it may happen that processes inherently associated with climate add further complexity. As shown in several studies, including ours (King et al. 1997; Angeler et al. 2002a, b; Ortega-Mayagoitia et al. 2002a, b), the role of cyprinids, the dominant (often non-planktivorous) fishes in Mediterranean ecosystems (Doadrio 2002), can importantly affect interactions between sediments and the water column, including food web characteristics. Although they clearly influence food web dynamics, no generalizations can be made on the magnitude and importance of influence. Ontogenetic shifts in habitat and food selection with fish age (Mittelbach \& Persson 1998) and the benthic feeding of most adult cyprinids (Doadrio 2002) truncate the pelagic trophic cascade. Therefore, sediment-pelagic interactions modify species richness and water quality features that, in turn, impinge on trophic cascade functioning in a feedback response that has not been studied yet. Recent research also suggests that the influence of bottom-up forces is higher in Mediterranean limnosystems (Moss et al. 2004).

Until now, we have provided a few examples that highlight differences between cold temperate and Mediterranean limnosystems indicating that the latter merit further research with independent models. Most Mediterranean limnology has been undertaken in Italy, Australia, Israel, California and Spain, with interesting contributions from Chile, South Africa, France and Greece. Unfortunately, contributions by the Arabic countries of the Mediterranean basin, including Turkey, are scarcer and frequently published in journals with very restricted distribution. Table 2 shows a short account of studies on Mediterranean limnology where we have intended to include studies from most countries experiencing Mediterranean climate.

We can summarize the current status of Mediterranean limnology as the following: it is an underdeveloped branch of limnology. Many of its current models (either conceptual or mathematical) are unsatisfactory and many studies are compromised by the fact that researchers forced their results inappropriately into contemporary conceptual frameworks valid only for other climatic regions. 
Tab. 2. Some limnological studies from Mediterranean areas of the World. Despite much of it is included in grey literature, we have only included published studies with ordinary distribution to make it easier for the concerned reader to dig deeper. In addition to the whole proceedings of the Societas Internationalis Limnologiae, some Mediterranean-specific limnology serials have been checked in its entirety, such as Memorie dell'Istituto Italiano di Idrobiologia (now Journal of Limnology), Limnetica and Marine and Freshwater Research. Also, the worldwide web has been searched for. An attempt has been made to search for limnological papers of all Mediterranean countries, but success was not always achieved. Since there are many studies in some areas, we have had to perform a selection which (it is obvious) will not satisfy everybody, but we think it is very representative of current knowledge on Mediterranean limnosystems and its gaps. Some recent EU research projects on limnology partly devoted to the Mediterranean basin are also reported at the end of the overview.

TOPIC REFERENCES

Monographs and reviews

Mediterranean floras, faunas and their distribution

Studies on Mediterranean specific-sites

Preliminary surveys and monitoring

Physical limnology

Lake and wetland biogeochemistry

Stream biogeochemistry, including decomposition

Plankton structure and dynamics

Benthos structure and dynamics

Fish

Food webs

Long-term studies
Akbulut (2004), Allanson (2004), Allanson et al. (1990), Alonso (1998), Alvarez-Cobelas \& Cirujano (1996), Bonacina \& Baudo (2001), Boulton \& Brook (1999), Chergui et al. (1999), Davies et al. (1994, 1995), De Deckker \& Williams (1986), Di Castri \& Mooney (1973), Gagneur \& Kara (2001), Gasith \& Resh (1999), Grove \& Rackham (2001), Guilizzoni et al. (1992), Jaouali (1995), Karaman \& Beeton (1981), Lassere \& Marzollo (2000), Montes \& Duarte (1992), Peduzzi et al. (1998), Prat \& Ward (1994), Prat et al. (1984), Rzóska \& Talling (1976), Serruya (1978), Serruya \& Pollingher (1983), Stanković (1960), VV.AA. (1989), Warner \& Hendrix (1984)

Alonso (1996), Bunn \& Davies (1990), Campaioli et al. (1994), Cirujano \& Medina (2002), Cook (2004), Doadrio (2001), Margaritora (1985), Naselli-Flores et al. (1998), Stanković (1955), Systematique des Organismes des Eaux Continentales Françaises (1981-1993)

Bazzanti et al. (2000), Bayly (2002), Boix et al. (2000), Cianficconi \& Moretti (1988), CottaRamusino et al. (1991), Di Giovanni (1966), El Mezdi (1985), Ferrari et al. (1993), Gagneur (1994), Hillman \& Shiel (1991), Hutchinson et al. (1932), Margalef (1948), Moretti (1949, 1953), Naselli-Flores \& Barone (2002), Pevalek (1935), Ramón et al. (1993), Soria \& Alfonso (1993), Stanković (1931, 1955, 1958)

Bahhou et al. (2000), Barbanti et al. (1971), Burgis \& Symoens (1987), Calvo et al. (1993), Elster \& Vollenweider (1961), Gessner (1957), Giudicelli et al. (1985), Margalef et al. (1976), Mitamura et al. (1997), Ramos et al. (1998), Rodrigues Capitulo et al. (1994), Saad (1978), Saad \& Hemeda (2001), Sechi \& Mosello (1985), Vicente et al. (1993)

Ambrosetti \& Barbanti (2002), Barbanti et al. (1981), Clark \& Hudson (2001), Colomer \& Casamitjana (1993), Colomer et al. (2001), Di Cola et al. (1977), Imberger (1985), Jellison et al. (1993), Kirk (1994), MacIntyre (1993), MacIntyre et al. (1999), Marcé et al. (2004), Piontelli \& Tonolli (1964), Vila \& Abella (1993)

Adams et al. (2000), Astorga et al. (1993), Boon (2000), Boon et al. (2000), Callieri et al. (1986), Comín (1984), Corbella et al. (1956), Curco et al. (2002), Forés \& Comín (1991), Golterman (1995), Golterman et al. (1998), Hambright \& Eckert (2001), Lamontagne (2002), López et al. (2001), Mosello (1981), Petrović (1975), Vollenweider (1956, 1963)

Butturini \& Sabater (1998), Harris (2001), Hart et al. (1991), Maamri et al. (1994), Maltchik et al. (1998), Martí \& Sabater (1996), Martí et al. (2004), McKergow et al. (2003), Mollá et al. (1998), Pattee et al. (2000), Robertson et al. (1999), Romaní et al. (2004), Suárez \& Vidal-Abarca (2000), Webster et al. (2001)

Albay et al. (2003), Aleem \& Samaan (1969), Alvarez-Cobelas \& Rojo (1994), Baldi (1943), Bertoni \& Callieri (1999), Calderón-Paz et al. (1993), Callieri \& Heinimaa (1997), Cassie (1967), De Bernardi (1974), Gasol et al. (2002), Guerrero et al. (1975, 1987), Hamza et al. (1993), Janasch (1958), Legendre \& Trousselier (1988), Miracle (1975), Ocevski (1966), Padan \& Shilo (1969), Peters (1985), Pirocchi (1947), Planas (1973), Pugnetti et al. (1992), Ravera (1954), Salmaso et al. (2003), Tafas \& Economou-Amilli (1991), Tonolli \& Tonolli (1951), Tonolli et al. (1967)

Aboal et al. (2000), Adams et al. (1978), Canteras (1985), Gell et al. (2002), Gommes \& Muntau (1981), Habdija et al. (2000), Howard-Williams (1978), Metzeling et al. (2002), Prat \& Bonada (2002), Prat \& Rieradevall (1995), Resh et al. (1990), Rossi et al. (2003), Sabater et al. (2004), Sommer \& Horwitz (2001), Stanković (1951)

Berg \& Grimaldi (1966), Gasith et al. (1998), Granado-Lorencio (1991), Morgan et al. (2002), Moyle et al. (1982), Vargas \& Sostoa (1996)

Angeler et al. (2003), Balcombe \& Closs (2004); Covich \& Knežević (1978), De Bernardi \& Giussani (1975), Giussani (1974), Giussani et al. (1990), Gophen \& Serruya (1990), Gophen et al. (1991), King et al. (1997), Kitchell et al. (1978), Manca \& Ruggiu (1998), Margaritora et al. (2001), Ortega-Mayagoitia et al. (2002a, b), Robertson et al. (1997), Točko (1966), Vighi et al. (1995)

Berman et al. (1995), De Bernardi \& Soldavini (1976), Morabito \& Pugnetti (1999), Ruggiu et al. (1998a), Zohary (2004) 
Tab. 2. Continuation.

\begin{tabular}{ll}
\hline TOPIC & REFERENCES \\
\hline Palaeolimnology & Aleem (1961), Guilizzoni \& Oldfield (1996), Hutchinson (1970), Lami et al. (2000), Marchetto \& \\
& Lami (1994), Margalef (1957), Ruggiu et al. (1998b) Schmidt et al. (2000), Valero-Garcés (2003) \\
$\begin{array}{l}\text { Environmental problems including water } \\
\text { pollution and eutrophication }\end{array}$ & $\begin{array}{l}\text { Alvarez-Cobelas } \text { et al. (1992b), De Bernardi } \text { et al. (1996), Gaggino \& Provini (1988), Gophen } \\
\text { (2000), Lake (2003), Wynne \& Parparova (2002) }\end{array}$ \\
Techniques for biological monitoring & Alba-Tercedor \& Pujante (2000), Buffagni et al. (2001), Davies (2000) \\
Human culture and Mediterranean & Alvarez-Cobelas \& Cirujano (1996), Bayly (1999), Blasco Ibáñez (1901), Haslam (1991), Haslam \\
limnosystems & \& Borg (1998), Infante don Juan Manuel (1325), Snowden (1999) \\
EU Projects dealing (at least partly) with & AL:PE, AQEM, AQUACON, BIOFILMS, BIOMAN, ECOFRAME, ERAS, EUREED I-II, \\
Mediterranean limnology & EUROLIMPACS, FIRELAB, MOLAR, NICOLAS, PALICLAS, STAR, STREAMES, SWALE, \\
& TEMPQSIM \\
\hline
\end{tabular}

\section{GAPS}

The review of limnological literature (Table 2) has enabled us to find some gaps in Mediterranean limnology that could be arranged broadly within the following topics.

Gaps related to Mediterranean geography or ecosystems.- Some geographical areas have been insufficiently surveyed and their researchers are still engaged in enumerating their aquatic floras and faunas. Interestingly, many systems have high EVT:Rainfall ratios. Hence the most classical topics of ecology, i.e. the adaptations of organisms to environmental processes could be relatively new for Mediterranean limnology, and yield surprising results. We will need more information from areas and habitats with poor limnological knowledge. These are the following.

1. More studies from Northern Africa, the Arabic Middle-East, Mediterranean Chile and Turkey are needed.

2. There are few studies on temporary streams and Mediterranean specific limnosystems (gnammas, sebkhas, vleis, etc.; Table 1) and hence they must be increased.

Hydrology and biogeochemistry relationships.Because water availability is essential for the survival of aquatic ecosystems, the regulation of their hydrological and biogeochemical processes must be studied jointly with more detail. More specifically, some research lines that are now poorly pursued will provide extremely interesting insights. These lines are the following:

1. The relationship between groundwaters and limnosystems has hardly been explored.

2. There are almost no studies on wetland biogeochemistry.

3. Very few studies exist on hyporheic biogeochemistry.

Biotic relationships.- The still poorly known aquatic floras and faunas of Mediterranean regions limit our understanding of biologically-mediated ecological proc- esses. It is clear that updated taxonomic treatments of Mediterranean animals and plants must be prepared as a tool for sound ecological research in Mediterranean limnosystems. This will result in disclosing a high variety of yet overlooked biotic relationships, such as

1. The role of cyprinid fish in food webs that deserves more research.

2. Bacterial growth and diversity in wetlands and streams mostly unknown.

3. Plankton-benthos linkages still unknown.

4. The functioning of submerged and emergent vegetation and their influence on limnological processes.

5. The study of impacts of Mediterranean-alien species (e.g. Dreissena, Procambarus, Eirocheir) on food webs and ecological processes that has not been started yet or is poorly understood.

Overall approaches.- Limnology is a synthetic science and, from the very beginning (Forbes 1887), it has pursued an integrative view. Despite many holistic claims (e.g. Margalef 1983), Mediterranean limnology is still in its infancy concerning ecosystem approaches. It is time to start ecosystem, biome and even regional studies, linking processes across terrestrial and aquatic boundaries in Mediterranean areas of the World. Latitude has been shown to be a poor descriptor of overall limnological processes (Kalff 1991), but regional approaches will certainly produce surprising results and applications to tackle forthcoming threats, such as those of climatic change. Holistic topics to be considered are:

1. The landscape approach of limnosystem study, which is absent and has certainly proved to be very fruitful to explain overall processes, both in streams (Johnson et al. 1997) and in lakes (Riera et al. 2000).

2. The availability of limnosystem models, either heuristic or predictive, conceptual or numeric, which is still lower than the vast array of items from cold temperate areas (e.g. Reynolds et al. 2001; Sommer et al. 1986; Straskraba \& Tundisi 1999).

3. Long-term studies exist in very low numbers, compared with long-term cold temperate surveys 
(e.g. Talling 1993; Bäuerle \& Gaedke 1998). Those studies will not only help to understand climate change but also illuminate shorter-term processes arising from seasonal and interannual environmental variability (Neale et al. 1991).

4. Climate change effects that can be hardly envisaged.

Applied topics.- These topics will not only aid in preserving Mediterranean limnosystems, but will provide also information on their economic value and the economic losses produced if they are impaired or even disappear. Some of them include:

1. Limnosystem services that have not been emphasized enough. This is an expanding topic throughout the world (Costanza et al. 1997) but remains to be carried out with Mediterranean limnosystems.

2. Measures for mitigating damage caused by climate change that will have to be developed for Mediterranean limnosystems.

\section{THE FUTURE}

The future of Mediterranean limnology as a science will depend on the survival of Mediterranean limnosystems which, in turn, will depend on water use and politics. The near future (roughly 100 years ahead) for Mediterranean limnology is not an optimistic one, however, as future scenarios of global climate change predict. In Mediterranean areas, lower and seasonally more irregular rainfall and higher air temperatures are expected (Bolle 2003), resulting in reduced water availability for surface and aquifer systems. Conversely, the socioeconomy of many Mediterranean areas will increasingly depend on agriculture and/or tourism, which are very water-demanding sectors (Gleick 1993). This will result in a conflict in which Mediterranean limnosystems will have the lowest societal priority. In the worst case many Mediterranean limnosystems and their invaluable cultural and biological legacy will be condemned to go extinct.

Prompt societal responses, including sustainable water use, to climate change are therefore key factors for the future of Mediterranean limnosystems. We acknowledge that only a few long-term data exist (but see the exceptional studies on Italian subalpine lakes and Lake Kinneret; table 2) on predicting the likely effects of climate change on our systems of interest but some prospective opinions reported by Spanish limnologists, working for at least 10 years in some systems that they know well, suggest that the effects of climate change will be very important in limnosystems (Alvarez-Cobelas et al. 2005). More specifically, the topics covered have been the persistence of the ecosystem (will it survive or not?), its size (will it stay permanent or become temporary?), its biogeochemistry and biota (will they be altered by climate change?). We have also asked about likely semiquantitative effects of climate change, and assigned them to categories from 0 (nil effect) to 4 (very strong effect). The overall conclusion is that the impacts generated by climate change will be very variable, and that streams appear to be less importantly affected in comparison with lentic water bodies (Fig. 8).

A strong argument to support more research on Mediterranean limnology comes from the fact that climate change will probably make cold temperate limnosystems more similar to what Mediterranean limnosystems are now (Arnell et al. 1996). So further improvement of Mediterranean studies will be very useful because it will provide reference conditions for cold temperate systems.

What about mitigation measures on the effects of climate change on Mediterranean limnosystems? Some could be the following:

$\left.1^{\text {st }}\right)$ Mediterranean limnosystems should be given more priority in the societal needs.

$2^{\text {nd }}$ ) Water-saving measures should be implemented immediately, instead of destructive and in terms of efficiency short-lived intercatchment water diversions, to supply Mediterranean tourist and agricultural sectors with water.

$3^{\text {rd }}$ ) Developing and/or improving wastewater treatment and recycling.

$4^{\text {th }}$ ) Increasing revegetation in catchments to mitigate pollution.

$5^{\text {th }}$ ) Increasing environmental protection of valuable limnosystems, also enhancing connectivity among them.

\section{CONCLUSIONS}

Our preceding description of the current state, gaps and prospects of Mediterranean limnology allows us to arrive at some general conclusions.

$1^{\text {st }}$ ) Mediterranean limnosystem types are very rich, but the ecology of most is poorly known.

$2^{\text {nd }}$ ) Current models of cold temperate limnosystems have very restricted geographical application and Mediterranean limnosystems do not meld with them.

$3^{\text {rd }}$ ) More research is urgently needed.

$4^{\text {th }}$ ) More people and more funding must be devoted to Mediterranean limnology. These goals can be achieved partly by recruiting young and qualified personnel. A prerequisite, however, shall be a less burdensome and longer-term working perspective.

$5^{\text {th }}$ ) Many endangered Mediterranean limnosystems will survive if, and only if, Mediterranean societies appreciate them (which is not the case right now).

$6^{\text {th }}$ ) If Mediterranean societies continue to ignore the importance of their limnosystems, then it will occur what the great Sicilian writer Leonardo Sciascia (1983) so cleverly wrote more than 20 years ago: "I fiumi sono mito e memoria, s'appartengono ai "verdi paradisi" dell'infanzia" [rivers are myth and memory, they belong to the "green paradise" of childhood]. 

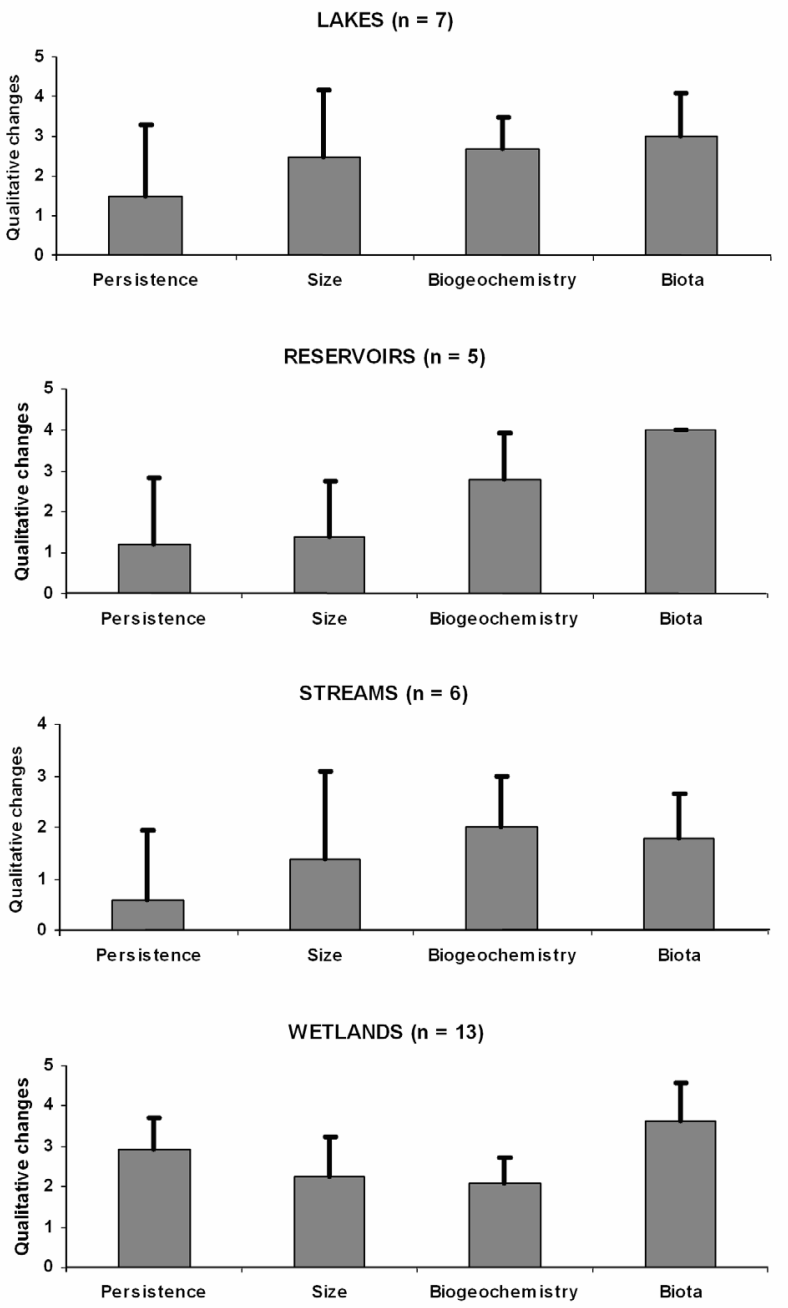

Fig. 8. Average and standard deviations of changes in response to climate change based on prospects of Spanish limnologists on the limnosystems they know best. The figure has been drawn from data reported in Alvarez-Cobelas et al. (2005). Qualitative changes after a century of climate change have been suggested for the persistence of ecosystems (change from permanent to temporary nature), even considering their disappearance (a value of 4), their size (0-no change; 4-very strong reduction in size), biogeochemistry ( 0 -null change, 4 -very strong change) and biotic communities ( 0 -null change, 4-very strong change).

\section{ACKNOWLEDGMENTS}

We would like to express our sincerest thanks to the Associazione Italiana di Oceanologia e Limnologia for having invited the senior author to its XVI congress. Giusseppe Morabito (CNR-Institute of Ecosystem Study, Italy) and Luigi Naselli-Flores (Univ. Palermo, Italy) have been the people responsible for arranging both the presentation and the stay of Miguel AlvarezCobelas at Terrasini (Palermo) in October 2004, for which we are very grateful. Many Mediterranean people have helped us with compiling table 1. Elisa Piña (Centro de Ciencias Medioambientales, Spain) was crucial in obtaining much older limnological literature during her stay at the Swiss EAWAG. Santos Cirujano (Real Jardín Botánico de Madrid, Spain), Jose Luis Velasco, Oscar Soriano and Rafael Araujo (Museo Nacional de Ciencias Naturales, Spain) provided valuable information on Mediterranean floras and faunas. Projects REN02-00558 and BOS02-2333 of the Spanish Ministry of Education and Science have partly funded this contribution. Also, this overview has partially been supported by a grant from the Conselleria d'Empresa, Universitat y Ciència (GRUPOS-2004/20, Generalitat Valenciana, Spain).

\section{REFERENCES}

Aboal, M., M.A. Puig, H. Ríos \& E. López-Jiménez. 2000. Relationship between macroinvertebrate diversity and toxicity of Cyanophyceae (Cyanobacteria) in some streams from Eastern Spain. Verh. int. Ver. Limnol., 27: 555-559.

Adams, M.S., P. Guilizzoni \& S. Adams. 1978. Relationship of dissolved inorganic carbon to macrophyte photosynthesis in some Italian lakes. Limnol. Oceanogr., 23: 912-919.

Adams, D.D., I. Vila, J. Pizarro \& C. Salazar. 2000. Gasses in the sediments of two eutrophic Chilean reservoirs: 
potential sediment oxygen demand and sediment-water flux of $\mathrm{CH}_{4}$ and $\mathrm{CO}_{2}$ before and after an El Niño event. Verh. int. Ver. Limnol., 27: 1376-1381.

Akbulut, N.E. 2004. Limnology in Turkey. In: Gopal, B. \& R.G. Wetzel (Eds), Limnology in developing Countries 4. SIL and International Scientific Publications, New Delhi: 171-218.

Alba-Tercedor, J. \& A. Pujante. 2000. Running-water biomonitoring in Spain. Opportunities for a predictive approach. In: Wright J.F., DW. Sutcliffe \& M.T. Furse (Eds), Assessing the biological quality of freshwater. RIVPACS and similar techniques. Freshwater Biological Association, Ambleside (Cumbria, UK): 207-216.

Albay, M., R. Akcaalan, H. Tufekci, J.S. Metcalf, K.A. Beattie \& G.A. Codd. 2003. Depth profiles of cyanobacterial hepatotoxins (microcystins) in three Turkish freshwater lakes. Hydrobiologia, 505: 89-95.

Aleem, A.A. 1961. Ecology of diatoms in the Ancient Fayoum Lake (Upper Egypt). Verh. int. Ver. Limnol., 14: 918-919.

Aleem, A.A. \& A.A. Samaan. 1969. Productivity of Lake Mariut, Egypt. Part II. Primary production. Int. Revue ges. Hydrobiol., 54: 491-527.

Allanson, B.R. 2004. Limnology in South Africa: Past and present status and future needs. In: Gopal, B. \& R.G. Wetzel (Eds), Limnology in developing Countries 4. SIL and International Scientific Publications, New Delhi: 1-116.

Allanson, B.R., R.C. Hart, J.H. O'Keeffe \& R.D. Robarts (Eds) 1990. Inland Waters of Southern Africa. An Ecological Perspective. Kluwer Academic Publishers. Dordrecht: 458 pp.

Alonso, M. 1996. Fauna Iberica 7: Crustacea Branchiopoda. Museo Nacional de Ciencias Naturales (CSIC). Madrid: $486 \mathrm{pp}$.

Alonso, M. 1998. Las lagunas de la España peninsular. Limnetica, 15: 1-176.

Alvarez-Cobelas, M. \& S. Cirujano (Eds). 1996. Las Tablas de Daimiel: Ecología acuática y Sociedad. ICONA, Madrid: $384 \mathrm{pp}$.

Alvarez-Cobelas, M. \& C. Rojo. 1994. Spatial, seasonal and long term variability of phytoplankton photosynthesis in lakes. J. Plankton Res., 16: 1691-1716.

Alvarez-Cobelas, M., F.J. Haering, J.L. Velasco \& A. Rubio. 1992a. The seasonal productivity of phytoplankton in a hypertrophic, gravel pit lake. J. Plankton Res., 14: 979-995.

Alvarez-Cobelas, M., P. Muñoz, A. Rubio \& N. Prat. 1992b. Current state of eutrophication in Spanish inland waters. European Water Pollution Control, 2(5): 27-32.

Alvarez-Cobelas, M. R. Castelló, S. Cirujano, C. Rojo \& M.A. Rodrigo. 2004. La contaminación de las lagunas de Ruidera. Actas de las II Jornadas sobre el Medio Natural Albacetense: 293-301.

Alvarez-Cobelas, M., J. Catalan \& D. García de Jalón. 2005. Impacts on inland aquatic ecosystems. In: J.M. Moreno (Ed.), Effects of Climate Change in Spain. Ministerio de Medio Ambiente, Madrid.

Ambrosetti, W. \& L. Barbanti. 2002. Physical limnology of Italian lakes. 2. Relationships between morphometric parameters, stability and Birgean work. J. Limnol., 61: 159-167.

Angeler D.G., M. Alvarez-Cobelas, S. Sanchez-Carrillo \& M.A. Rodrigo. 2002a. Assessment of exotic fish impacts on water quality and zooplankton in a degraded semi-arid floodplain wetland. Aquat. Sci., 64: 76-86.

Angeler, D. G., M.A. Rodrigo, S. Sánchez-Carrillo \& M. Alvarez-Cobelas. 2002b. Effects of hydrologically confined fish on bacterioplankton and autotrophic picoplankton in a semiarid marsh. Aquat. Microb. Ecol., 29: 307-312.

Angeler, D.G. \& M.A. Rodrigo. 2004. Ramp disturbanceramp response: a simple model for wetland disturbance ecology. Mar. Freshwat. Res., 55: 33-37.
Angeler, D.G., P. Chow-Fraser, M.A. Hanson, S. SánchezCarrillo \& K.D. Zimmer. 2003. Biomanipulation: a useful tool for freshwater wetland mitigation? Freshwat. Biol., 48: 2203-2213.

Arnell, N., B. Bates, H. Lang, J.J. Magnuson \& P. Mulholland. 1996. Hydrology and freshwater ecology. In: Houghton, J.T., L.G. Meira Filho, B.A. Callander, N. Harris, A. Kattenberg \& K. Maskell (Eds), Climate Change 1995. Cambridge University Press, Cambridge: 325-363.

Astorga, V.N., E. Novella \& F.A. Comín. 1993. Denitrification related to organic matter in rice field sediments. Verh. int. Ver. Limnol., 25: 1365-1368.

Bahhou, J., Ngandum M.A. \& L. Aleya. 2000. Annual changes in the biochemical composition of the phytoplankton in the Idris First Reservoir. Verh. int. Ver. Limnol., 27: 2261-2268.

Balcombe, S.R. \& G.P. Closs. 2004. Spatial relationships and temporal variability in a littoral macrophyte fish assemblage. Mar. Freshwat. Res., 55: 609-617.

Baldi, E. 1943. Condizioni spaziali della distribuzione del limnoplancton. Boll. Zool., 14: 5-32.

Barbanti, L., G. Bonomi, A. Carollo, G. Chiaudani, I. Ferrari, M. Gerletti, A.M. Nocentini, D. Ruggiu \& L. Tonolli. 1971. Limnologia ed Ecologia dei Laghi di Bolsena, Bracciano, Trasimeno \& Vico: Situazione attuale \& prevedibili Conseguenze derivanti da una loro Utilizzazione multipla. Ed. Istituto Italiano di Idrobiologia, Pallanza: 263 pp.

Barbanti, L., W. Ambrosetti \& A. Rolla. 1981. Dipendenza della temperatura dell'acqua superficiale da temperatura atmosferica \& radiazione solare nei laghi italiani. Mem. Ist. ital. Idrobiol., 39: 65-98.

Bäuerle, E. \& U. Gaedke. (Eds) 1998. Lake Constance. Characterization of an ecosystem in transition. Arch. Hydrobiol., Adv. Limnol., 53: 1-610.

Bayly, I.A.E. 1999. Rock of Ages: Human Use and Natural History of Australian Granites. University of Western Australia Press, Nedlands: 132 pp.

Bayly, I.A.E. 2002. The life of temporary waters in Australian gnammas (rock-holes). Verh. int. Ver. Limnol., 28: 41-48.

Bazzanti, M., M. Seminara, S. Baldoni \& A. Stella. 2000. Macroinvertebrates and environmental factors of some temporary and permanent ponds in Italy. Verh. int. Ver. Limnol., 27: 936-941.

Berg, A. \& E. Grimaldi. 1966. Biologia dell'agone (Alosa ficta lacustris) del Lago Maggiore. Mem. Ist. ital. Idrobiol., 20: 41-83.

Berman, T., L. Stone, Y.Z. Yacobi, B. Kaplan, M. Schlichter, A. Nishri \& U. Pollingher. 1995. Primary production and phytoplankton in Lake Kinneret: a long-term record (1972-1993). Limnol. Oceanogr., 40: 1064-1076.

Bertoni, R. \& De Bernardi, R. 1997. Ragioni, storia e prospettive della limnologia italiana. Realtá Nuova, 62(5): 24-40.

Bertoni, R. \& C. Callieri. 1999. The role of UV-B radiation on freshwater autotrophic and heterotrophic picoplancton in a subalpine lake. J. Plankton Res., 21: 1373-1388.

Birot, P. 1970. Les Régions naturelles du Globe. Masson et Cie, Paris: 380 pp.

Blasco Ibáñez, V. 1901. Cañas y Barro. Edición de 1998. Alianza editorial, Madrid: $277 \mathrm{pp}$.

Boix, D., J. Sala \& R. Moreno-Amich. 2000. Succession of the invertebrate community in a temporary pond. Verh. int. Ver. Limnol., 27: 2586-2593.

Bonacina, C. \& R. Baudo (Eds). 2001. Lake Orta: a Case Study. J. Limnol., 60(2).

Bolle, H.J. (Ed.) 2003. Mediterranean Climate. Variability and Trends. Springer Verlag, Berlin: $320 \mathrm{pp}$.

Boon, P.I. 2000. Carbon cycling in Australian wetlands: the importance of methane. Verh. int. Ver. Limnol., 27: 37-50. 
Boon, P.I., K.L. Muller \& G.G. Ganf. 2000. Methane emissions from diverse wetlands in south-eastern Australia. Verh. int. Ver. Limnol., 27: 1382-1386.

Boulton, A.J. \& M.A. Brock. 1999. Australian Freshwater Ecology. Processes and Management. Gleneagles Publishing, Adelaide: $300 \mathrm{pp}$.

Buffagni, A., J.L. Kemp, S. Erba, C. Belfiore, D. Hering \& O. Moog. 2001. A Europewide system for assessing the quality of rivers using macroinvertebrates: the AQEM Project and its importance for Southern Europe (with special emphasis on Italy). J. Limnol., 60 (Suppl. 1): 9-48.

Bunn, S.E. \& P.M. Davies. 1990. Why is the stream fauna of south-western Australia so impoverished? Hydrobiologia, 194: 169-196.

Burgis, M.J. \& J.J. Symoens (Eds) 1987. African Wetlands and shallow Water Bodies. Editions de l'ORSTOM, Paris: $650 \mathrm{pp}$.

Butturini, A. \& F. Sabater. 1998. Ammonium and phosphate retention in a Mediterranean stream. Hydrological versus temperature control. Can. J. Fish. Aquat. Sci., 55: 19381945.

Calderón-Paz, J.I., J. García-Cantizano, D. Vaqué \& C. Pedrós-Alió. 1993. Heterotrophic bacterial production in systems of the northern Spanish Mediterranean Region. Verh. int. Ver. Limnol., 25: 739-741.

Callieri, C. \& S. Heinimaa. 1997. Microbial loop in the large subalpine lakes. Mem. Ist. ital. Idrobiol., 56: 143-156.

Callieri, C., R. Bertoni \& M. Contesini. 1986. Settling rates of particulate matter in Lago di Mergozzo (Northern Italy). Mem. Ist. ital. Idrobiol., 44: 147-164.

Calvo, S., R. Barone, L. Naselli Flores, C. Fradà Orestano, G. Dongarrà, A. Lugaro \& G. Genchi. 1993. Limnological studies on lakes and reservoirs of Sicily. Naturalista sicil., 17 suppl.: $1-292$.

Campaioli, S., P.F. Gheti, A. Minelli \& S. Ruffo, S. 1994 Manuale per il Riconoscimento dei Macroinvertebrati delle Acque dolci italiane. Vol. I. Litografica Saturnia, Trento: $357 \mathrm{pp}$

Canteras, J.C. 1985. Study of the relationship between chemolithotrophic denitrifying and sulphate-reducing bacteria in River Cubillas (Granada, Spain). Verh. int. Ver. Limnol., 22: 2077-2080.

Carney, H.H. \& J.J. Elser. 1990. Strength of zooplanktonphytoplankton coupling in relation to lake trophic state. In Tilzer, M.M. \& C. Serruya (Eds), Large Lakes. Springer Verlag, Berlin: 615-631.

Carpenter, S.R. \& J.F. Kitchell (Eds) 1993. The trophic Cascade in Lakes. Cambridge University Press, Cambridge: $385 \mathrm{pp}$.

Cassie, R.M. 1967. Principal component analysis of the zooplankton of Lake Maggiore 1957-1958. Mem. Ist. ital. Idrobiol., 21: 129-144.

Chergui, H., E. Pattee, K. Essafi \& M.A. Mhamdi. 1999. Moroccan limnology. In: Wetzel, R.G. \& B. Gopal (Eds), Limnology in developing Countries 2. SIL and International Scientific Publications, New Delhi: 235-330.

Cianficconi, F. \& G.P. Moretti. 1988. Ecology and zoogeography of the macrobenthos in the irrigated meadows or "Marcite" of Central Italy (Umbria-PG). Verh. int. Ver. Limnol., 25: 1068-1073.

Cirujano, S. \& L. Medina. 2002. Plantas acuáticas de las Lagunas y Humedales de Castilla-La Mancha. Junta de Comunidades de Castilla-La Mancha y CSIC, Madrid: 340 pp.

Clark, J.F. \& G.B. Hudson. 2001. Quantifying the flux of hydrothermal fluids into Mono Lake by use of helium isotopes. Limnol. Oceanogr., 46: 189-196.

Colomer, J. \& X. Casamitjana. 1993. A model to calculate surface energy fluxes from routine meteorological data. Application to Lake Banyoles. Verh. int. Ver. Limnol., 25: 88-91
Colomer, J., T. Serra, J. Piera, E. Roget \& X. Casamitjana. 2001. Observations of a hydrothermal plume in a karstic lake. Limnol. Oceanogr., 46: 197-203.

Comín, F.J. 1984. Características físicas y químicas y fitoplancton de algunas lagunas costeras (Encanyissada, Tancada y Buda) (Delta del Ebro). Oecol. Aquat., 7: 79162.

Connell, J. 1978. Diversity in tropical rain forests and coral reefs. Science, 199: 1304-1310.

Cook, C.D.K. 2004. Aquatic and Wetland Plants of Southern Africa. Backhuys Publishers, Leiden, The Netherlands: $282 \mathrm{pp}$.

Corbella, C., N. Della Croce \& O. Ravera. 1956. Plancton, bentos \& chimismo delle acque \& dei sedimenti in un lago profondo (Lago Maggiore). Mem. Ist. ital. Idrobiol., 9: 125-264.

Costanza, R., R. d'Arge, R. de Groot, S. Farber, M. Grasso, B. Hannon, S. Naeem, K. Limburg, J. Paruelo, R.V. O'Neill, R. Raskin, P. Sutton \& M. van den Belt. 1997. The value of the world's ecosystem services and natural capital. Nature, 387: 253-260.

Cotta-Ramusino, M., G. Crosa \& A. Buffagni. 1991. Microhabitat preferences of benthic fauna (Ephemeroptera) in plane springs (fontanili). Verh. int. Ver. Limnol., 24: 16261628.

Covich, A.P. \& B. Knežević. 1978. Size-selective predation by fish on thin-shelled gastropods (Lymnaea); the significance of floating vegetation (Trapa) as a physical refuge. Verh. int. Ver. Limnol., 20: 2172-2177.

Curco, A., C. Ibañez, J.W. Day \& N. Prat. 2002. Net primary production and decomposition of salt marshes of the Ebre Delta (Catalonia, Spain). Estuaries, 25: 309-324.

Davies, B.R., M.C. Thoms, K.F. Walker, J.H. O'Keeffe \& JA. Gore. 1994. Dryland rivers: their ecology, conservation and management. In: Calow, P. \& G.E. Petts (Eds), The Rivers Handbook. Blackwell Science, Oxford: 484-511.

Davies, B.R., J.H. O'Keeffe \& C.D. Snaddon. 1995. River and stream ecosystem in Southern Africa: predictable unpredictable. In: Cushing C.E., K.W. Cummins \& G.W Minshall (Eds), River and Stream Ecosystems. Elsevier, Amsterdam: 537-599.

Davies, P.E. 2000. Development of a national river bioassessment system (AUSRIVAS) in Australia. In: Wright, J.F., D.W. Sutcliffe \& M.T. Furse (Eds), Assessing the Biological Quality of Fresh Waters: RIVPACS and other Techniques. Freshwater Biological Association, Ambleside (Cumbria, UK): 113-124.

de Bernardi, R. 1974. The dynamics of a population of Daphnia hyalina Leydig in Lago Maggiore, Northern Italy, Mem. Ist. ital. Idrobiol., 31: 221-243.

de Bernardi, R. \& G. Giussani. 1975. Population dynamics of three cladocerans of Lago Maggiore related to predation pressure by a planktophagous fish. Verh. int. Ver. Limnol., 19: 2906-2912.

de Bernardi, R. \& E. Soldavini. 1976. Long term fluctuations of zooplankton in Lake Mergozzo, Northern Italy. Mem. Ist. ital. Idrobiol., 33: 345-375.

de Bernardi, R., A. Calderoni \& R. Mosello. 1996. Environmental problems in Italian lakes, and lakes Maggiore and Orta as successful examples of correct management leading to restoration. Verh. int. Ver. Limnol., 26: 123-138.

De Deckker, P. \& W.D. Williams (Eds). 1986. Limnology in Australia. CSIRO and Dr. W. Junk Publishers, Melbourne and Dordrecht: $671 \mathrm{pp}$.

Di Castri, F. \& H.A. Mooney (Eds). 1973. Mediterranean Type Ecosystems. Origin and structure. Springer Verlag, Berlin: $405 \mathrm{pp}$.

Di Cola, G., M. Diligenti \& L. Guerri. 1977. Identification of the thermal eddy diffusivity in a stratified lake. Mem. Ist. ital. Idrobiol., 34: 175-185. 
Di Giovanni, M.V. 1966. Le colonizzazioni dei laghi agricoli nell'Italia Centrale. Verh. int. Ver. Limnol., 16: 1393-1404.

Doadrio, I. (Ed.) 2001. Atlas y Libro rojo de los Peces continentales de España. Ministerio de Medio Ambiente y CSIC, Madrid: 364 pp.

El Mezdi, Z. 1985. Les Khettaras de la région de Marrakech (Maroc): un biotope hydrobiologique remarquable. Verh. int. Ver. Limnol., 22: 2106-2109.

Elster, H.J \& R. Vollenweider. 1961. Beiträge zur Limnologie Ägyptens. Arch. Hydrobiol., 57: 241-343.

Ferrari, I., V.U. Cecchereli, M. Naldi \& P. Viaroli. 1993. Planktonic and benthic communities in a shallow-wate distrophic lagoon. Verh. int. Ver. Limnol., 25: 1043-1047.

Forbes, S.T. 1887. The lake as a microcosm. Bull. Peoria Sci. Assoc., 1887: 77-87.

Forel, F.A. 1889. Ricerche fisiche sui laghi d'Insubria. Rend. R. Ist. Lombardo, Ser. 2, 22: 739-742.

Forés, E. \& F.A. Comín. 1991. Rice water column sediment relationships in ricefields. Verh. int. Ver. Limnol., 25: 1560-1563.

Gaggino, G.F. \& A. Provini. 1988. Eutrophication of lakes and reservoirs in Italy. Verh. int. Ver. Limnol., 23: 553-557.

Gagneur, J. 1994. Flash floods and drying up as major disturbances upon benthic communities in North-African wadis. Verh. int. Ver. Limnol., 25: 1807-1811.

Gagneur, J. \& H. Kara. 2001. Limnology in Algeria. In: Wetzel, R.G. \& B. Gopal (Eds), Limnology in developing Countries 3. SIL and International Scientific Publications, New Delhi: 1-34.

Gasith, A. \& V.H. Resh. 1999. Streams in Mediterranean climate regions: Abiotic influences and biotic responses to predictable seasonal events. Annu. Rev. Ecol. Syst., 30: 51-81.

Gasith, A., M. Bing, Y. Raz \& M. Goren. 1998. Fish community parameters as indicators of habitat conditions: the case of the Yarqon, a lowland, polluted stream in semiarid region (Israel). Verh. int. Ver. Limnol., 26: 10231026.

Gasol, J.M., M. Comerma, J.C. García, J. Armengol, E.O. Casamayor, P. Kojecká \& K. Šimek. 2002. A transplant experiment to identify the factors controlling bacterial abundante, activity, production, and community composition in a eutrophic canyon-shaped reservoir. Limnol. Oceanogr., 47: 62-77.

Gell, P.A., I.R. Sluiter \& J. Fluin. 2002. Seasonal and interannual variations in diatom assemblages in Murray River connected wetlands in north-west Victoria, Australia. Mar. Freshwat. Res., 53: 981-992.

Gessner, F. 1957. Van Gölü, zur Limnologie des Grossen Soda Sees in Ost-Anatolien. Arch. Hydrobiol., 53: 1-22.

Giudicelli, J., M. Dakki \& A. Dia. 1985. Caractéristiques abiotiques et hydrobiologiques des eaux courantes méditerranéennes. Verh. int. Ver. Limnol., 22: 2094-2101.

Giussani, G. 1974. Planctofagia selettiva del coregone "bondella" (Coregonus sp.) del Lago Maggiore. Mem. Ist. ital. Idrobiol., 31: 181-203.

Giussani, G., R. de Bernardi \& T. Ruffoni. 1990. Three years of experience in biomanipulating a small eutrophic lake: Lago di Candia (Northern Italy). Hydrobiologia, 200/201: 357-366.

Gleick, P.H. (Ed.) 1993. Water in Crisis. Oxford University Press, Oxford: 453 pp.

Golterman, H.L. 1995. The labyrinth of nutrient cycles and buffers in wetlands: results based on research in the Camargue (Southern France). Hydrobiologia, 315: 39-58.

Golterman, H.L., P. Bruijn, J.G.M. Schouffoer \& E. Demoulin. 1998. Urea fertilization and the N-cycle of ricefields in the Camargue (S. France). Hydrobiologia, 384: 720 .

Gommes, R. \& H. Muntau. 1981. La composition chimique des limnophytes du Lac Majeur. Mem. Ist. ital. Idrobiol., 38: 237-307.
González Bernáldez, F. 1992. Los Paisajes del Agua. Terminología popular de Humedales. J.M. Reyero editor, Madrid: $257 \mathrm{pp}$.

Gophen, M. 2000. Lake Kinneret (Israel) ecosystem: longterm instability or resiliency? Water, Air Soil Pollut., 123: 323-335.

Gophen, M. \& C. Serruya. 1990. Fish predation effects on plankton communitiy structure in large lakes: Lake Kinneret. In: Tilzer, M.M. \& C. Serruya (Eds), Large Lakes. Springer-Verlag, Berlin: 645-660.

Gophen, M., P.D. Walline \& B. Azoulay. 1991. Associations between larval sardines and Peridinium patches in Lake Kinneret (Israel). Verh. int. Ver. Limnol., 24: 2537-2540.

Granado-Lorencio, C. 1991. 1991. Fish communities of Spanish reservoir systems: A non-deterministic approach. Verh. int. Ver. Limnol., 24: 2428-2432.

Grove, A.T: \& O. Rackham. 2001. The Nature of Mediterranean Europe: An ecological History. Yale University Press, New Haven: 384 pp.

Guerrero, R., F. Roda, C. Abella \& F. Torrella. 1975. Optimal growth temperatures and media parameters of bacterial communities from lakes of different trophic states. Verh. int. Ver. Limnol., 19: 2620-2626.

Guerrero, R., C. Pedrós-Alió, I. Esteve \& J. Mas. 1987. Communities of phototrophic sulfur bacteria in lakes of the Spanish Mediterranean region. In: Lindholm, T. (Ed.), Ecology of photosynthetic Prokaryotes with special Reference to meromictic Lakes and coastal Lagoons. Åbo Akademis Förlag, Åbo: 125-151.

Guilizzoni, P. \& F. Oldfield (Eds). 1996. Palaeoenvironmental Analysis of Italian Crater Lake \& Adriatic Sediments (PALICLAS). Mem. Ist. ital. Idrobiol., 55: 1-357.

Guilizzoni, P., G. Tartari \& G. Giussani (Eds). 1992. Limnology in Italy. Mem. Ist. ital. Idrobiol., 50: 1-491.

Habdija, I., I. Radanović \& R. Matoničkin. 2000. Functional feeding structure of benthic macroinvertebrates in travertine barrier biotopes. Verh. int. Ver. Limnol., 27: 2594-2599.

Hambright, K.D. \& W. Eckert. 2001. Sediment-phosphorus dynamics in newly created Lake Agmon (Agmon-Hula wetlands), Israel. Verh. int. Ver. Limnol., 27: 4001-4004.

Hamza, W., M. Manca \& D. Ruggiu. 1993. Field estimates of zooplankton community grazing in the limed Lago d'Orta (Italy) by the use of a radioisotope-free techniques. Hydrobiologia, 264: 47-54.

Harris, G.P. 1999. Comparison of the biogeochemistry of lakes and estuaries: ecosystem, processes, funtional groups, hysteresis effects and interactions between macroand microbiology. Mar. Freshwat. Res., 50: 791-811.

Harris, G.P. 2001. Biogeochemistry of nitrogen and phosphorus in Australian catchments, rivers and estuaries: effects of land use and flow regulation and comparisons with global patterns. Mar. Freshwat. Res., 52: 139-149.

Hart, B.T., P. Freeman, I.D. McKelvie, S. Pearse \& D.G. Ross. 1991. Phosphorus spiralling in Myrtle Creek, Victoria, Australia. Verh. int. Ver. Limnol., 24: 2065-2070.

Haslam, S.M. 1991. The Historic River. Cobden of Cambridge Press, Cambridge: 324 pp.

Haslam, S.M. \& J. Borg. 1998. The River Valleys of the Maltese Islands. Environment and Human Impact. Islands and Small States Institute (Malta) and CIHEAM (Bari, Italy): $330 \mathrm{pp.}$

Hillman, T.J. \& R.J. Shiel. 1991. Macro- and microinvertebrates in Australian billabongs. Verh. int. Ver. Limnol., 24: 1581-1587.

Howard-Williams, C. 1978. Growth and production of aquatic macrophytes in a south temperate saline lake. Verh. int. Ver. Limnol., 20: 1153-1158.

Hutchinson, G.E. (Ed.) 1970. Ianula: An account of the history and development of the Lago di Monterosi, Latium, Italy. Trans. Amer. Philos. Soc., 60(4): 1-178. 
Hutchinson, G.E., G.E. Pickford \& J.F.M. Schuurman. 1932. A contribution to the hydrobiology of pans and other inland waters of South-Africa. Arch. Hydrobiol., 24: 1152.

Imberger, J. 1985. The diurnal mixed layer. Limnol. Oceanogr., 30: 737-770

Infante don Juan Manuel. 1325. Libro de la Caza (Cetrería). Edition by J.M. Fradejas in 1991. Editorial Casariego, Madrid: $243 \mathrm{pp}$.

Janasch, H.W. 1958. Die bakterielle Rotfärbung der Salzseen der Wadi Natrum (Ägypten). Verh. int. Ver. Limnol., 13: 947-949.

Jaouali, J. 1995. Limnology in Tunisia. In: Gopal, B. \& R.G. Wetzel (Eds), Limnology in developing Countries 1. SIL and International Scientific Publications, New Delhi: 4162.

Jeftic, L., J.D. Milliman \& G. Sestini (Eds). 1992. Climatic Change and the Mediterranean. Edward Arnold, London: $673 \mathrm{pp}$.

Jellison, R., L.G. Miller, J.M. Melack \& G.L. Dana. 1993. Meromixis in hypersaline Mono Lake, California. 2. Nitrogen fluxes. Limnol. Oceanogr., 38: 1020-1039.

Jeppesen, E., J.P. Jensen, M. Søndergaard, T. Lauridsen \& F. Landkildheus. 2000. Trophic structure, species richness and biodiversity in Danish lakes: changes along a phosphorus gradient. Freshwat. Biol., 45: 201-218.

Johnson, L.B., C. Richards, G.E. Host \& J.W. Arthur. 1997. Landscape influences on water chemistry in Midwestern stream ecosystems. Freshwat. Biol., 37: 193-208.

Kalff, J. 1991. The utility of latitude and other environmental factors as predictors of nutrients, biomass and production in lakes worldwide: problems and alternatives. Verh. int. Ver. Limnol., 24: 1235-1239.

Kalff, J. 2002. Limnology: Inland Water Ecosystems. PrenticeHall Publishers, New Jersey: 592 pp.

Karaman, G.S. \& A.M. Beeton (Eds). 1981. The Biota and Limnology of lake Skadar. University Veljko Vlahovic of Titograd \& Smithsonian Institution of Washington: 275 pp.

King, A.J., A.I. Robertson \& M.R. Healey. 1997. Experimental manipulations of the biomass of introduced carp (Cyprinus carpio) in billabongs. I. Impacts on water-column properties. Mar. Freshwat. Res., 48: 435-443.

Kirk, J.T.O. 1994. Light and Photosynthesis in Aquatic Ecosystems. $2^{\text {nd }}$ edition. Cambridge University Press, Cambridge: $509 \mathrm{pp}$.

Kitchell, J.F., R.A. Stein \& B. Knežević. 1978. Utilization of filamentous algae by fishes in Skadar Lake, Yugoslavia. Verh. int. Ver. Limnol., 20: 2159-2165.

Lake, P.S. 2003. Ecological effects of perturbation by drought in flowing waters. Freshwat. Biol., 48: 1161-1172.

Lami, A., A. Marchetto, R. Lo Bianco, P.G. Appleby \& P. Guilizzoni. 2000. The last ca 2000 years palaeolimnology of Lake Candia (N. Italy): inorganic geochemistry, fossil pigments \& temperature time-series analyses. J. Limnol., 59: 31-46.

Lamontagne, S. 2002. Groundwater delivery of nitrate and predicted change in nitrate concentration in Blue Lake, South Australia. Mar. Freshwat. Res., 52: 1129-1142.

Lassere, P. \& A. Marzollo (Eds). 2000. The Venice Lagoon Ecosystem. UNESCO \& The Parthenon Publishing Group, Paris: $272 \mathrm{pp}$

Legendre, P. \& M. Troussellier. 1988. Aquatic heterotrophic bacteria: modeling in presence of spatial correlation. Limnol. Oceanogr., 33: 1055-1067.

Lewis jr., W.M. 1990. Comparisons of phytoplankton biomass in temperate and tropical lakes. Limnol. Oceanogr., 35: $1838-1845$

Likens, G.E. 1985. An Ecosystem approach to Aquatic Ecology. Mirror Lake and its Environment. Springer Verlag, New York: 516 pp.
López, P., J.A. Morguí, M. Vidal \& X. Lluch. 2001. Porewater composition and alkalinity balance in sediments of a meromictic coastal lagoon (Cibollar, Majorca, Spain). Verh. int. Ver. Limnol., 27: 3389-3393.

Maamri, A., H. Chergui \& E. Pattee. 1994. Allochthonous input of coarse particulate organic matter to a Moroccan mountain stream. Acta Oecologica, 15: 495-508.

MacIntyre, S. 1993. Mixing in the euphotic zone of a shallow, turbid lake: Consequences for the phytoplankton. Limnol. Oceanogr., 38: 798-817.

MacIntyre, S., K.M. Flynn, R. Jellison \& J.R. Romero. 1999. Boundary mixing and nutrient flux in Mono Lake, CA. Limnol. Oceanogr., 44: 512-529.

Maltchik, L., S. Mollá \& C. Casado. 1998. Spatio-temporal heterogeneity of nutrients in a mediterranean temporary stream (Montesina Stream, SW, Spain). Verh. int. Ver. Limnol., 26: 1062-1065.

Manca, M. \& D. Ruggiu. 1998. Consequences of pelagic foodweb changes during a long-term lake oligotrophication process. Limnol. Oceanogr., 43: 1368-1373.

Marcé, R., M. Comerma, J.C. García \& J. Armengol. 2004. A neuro-fuzzy modeling tool to estimate fluvial nutrient loads in watersheds under time-varying human impact. Limnol. Oceanogr. Methods 2: 342-355.

Marchetto, A. \& A. Lami. 1994. Reconstruction of $\mathrm{pH}$ by chrysophycean scales in some lakes of the Southern Alps. Hydrobiologia, 274: 83-90.

Margalef, R. 1948. Estudios sobre la vida en las aguas continentales de la región endorreica manchega. Publ. Inst. Biol. Apl. Barcelona, 4: 5-51.

Margalef, R. 1957. Paleoecología del lago de la Cerdaña. Publ. Inst. Biol. Apl. Barcelona, 25: 131-137.

Margalef, R. 1983. Limnología. Editorial Omega, Barcelona: $1010 \mathrm{pp}$

Margalef, R., J. Armengol, M. Estrada, A. Guiset, M.D. Planas, N. Prat, J. Toja \& A. Vidal. 1976. Limnología de los Embalses españoles. MOPU, Madrid: 422 pp. + appendices.

Margaritora, F.G. 1985. Cladocera. Editoriale Calderini, Bologna: 393 pp.

Margaritora, F.G., O. Ferrara \& D. Vagaggini. 2001. Predatory impact of the mosquitofish (Gambusia holbrooki Girard) on zooplanktonic populations in a pond at Tenuta di Castelporziano (Rome, Central Italy). $J$. Limnol., 60: 189-193.

Martí, E. \& F. Sabater. 1996. High variability in temporal and spatial nutrient retention in Mediterranean streams. Ecology, 77: 854-869.

Martí, E., J.L. Aumatell, L. Godé, M. Poch \& F. Sabater. 2004. Nutrient retention efficiency in streams receiving inputs from wastewater treatment plants. J. Environm. Qual., 33: 285-293.

Mayer, B., E.W. Boyer, C. Goodale, N.A. Jaworski, N. van Breemen, R.W. Howarth, S. Seitzinger, G. Billén, K. Lajtha, K. Nadelhoffer, D. van Dam, L.J. Hetling, M. Nosal \& K. Paustian. 2002. Sources of nitrate in rivers draining sixteen watersheds in the northeastern U.S.: Isotopic constrains. Biogeochemistry, 57/58: 171-197.

McKergow, L.A., D.M. Weaver, I.P. Prosser, R.B. Grayson \& A.E.G. Reed. 2003. Before and after riparian management: sediment and nutrient exports from a small agricultural catchment, Western Australia. J. Hydrol., 270: 253-272.

Metzeling, L., D. Robinson, S. Perriss \& R. Marchant. 2002. Temporal persistence of benthic invertebrate communities in south-eastern Australian streams: taxonomic resolution and implications for the use of predictive models. Mar. Freshwat. Res., 53: 1223-1234.

Miracle, M.R. 1975. Distribución en el Espacio y en el Tiempo de las Especies de Zooplancton del Lago de Banyoles. ICONA, Madrid: 272 pp. 
Mitamura, O., M. Nishimura, M. Tanaka \& A. Yayintaş. 1997. Comparative investigation of biogeochemical characteristics in the Anatolian lakes, Turkey. Verh. int. Ver. Limnol., 26: 360-368.

Mittelbach, G.G. \& L. Persson. 1998. The ontogeny of piscivory and its ecological consequences. Can. J. Fish. Aquat. Sci., 55: 1454-1465.

Molière [J.B. Pocquelin] 1670. Le Bourgeois Gentilhomme. In: Couton, G. (Ed.), Euvres Complètes, 2, Bibliothèque de La Pléiade. Edition de 1971. Editions Gallimard, Paris: $1584 \mathrm{pp}$.

Mollá, S., L. Maltchik, C. Casado \& C. Montes. 1998. Metabolism and nutrient assimilation by aquatic plants in a Mediterranean temporary system. Verh. int. Ver. Limnol., 26: 1066-1070.

Montes, C. \& C. Duarte (Eds). 1992. Limnology in Spain. Limnetica, 8: 1-277.

Morabito, G. \& A. Pugnetti. 1999. Long term changes of primary productivity during the trophic evolution of Lake Maggiore. Atti Associazione Italiana Oceanologia Limnologia, 13: 105-115.

Moretti, G.P. 1949. Vita nelle acque salse del sistema del Salino (Macerata). Verh. int. Ver. Limnol., 10: 339-343.

Moretti, G.P. 1953. I fattori ecologici che regolano la vita nelle acque correnti delle Alpi and degli Appennini. Mem. Ist. ital. Idrobiol., 7: 229-316.

Morgan, D.L., S.J. Hambleton, H.S. Gill \& S.J. Beattie. 2002. Distribution, biology and likely impacts of the introduced redfin perch (Perca fluviatilis) in Western Australia. Mar. Freshwat. Res., 53: 1211-1221.

Mosello, R. 1981. Chemical characteristics of fifty italian alpine lakes (Pennine-Lepontine Alps), with emphasis on the acidification problems. Mem. Ist. ital. Idrobiol., 39: 99-118.

Moss, B., D. Stephen, D.M. Balayla, E. Bécares, S.E Collings, C. Fernández-Aláez, C. Ferriol, P. García, J. Gomá, M. Gyllström, L.A. Hansson, J. Hietala, T. Kairesalo, M.R. Miracle, S. Romo, J. Rueda, V. Russell, A. Ståhl-Delbanco, M. Svensson, K. Vakkilainen, M Valentín, W.H. van de Bund, E. van Donk, E. Vicente \& M.J. Villena. 2004. Continental-scale pattern of nutrient and fish effects on shallow lakes: synthesis of panEuropean mesocosm experiments. Freshwat. Biol., 499: 1633-1649.

Moustaka-Gouni, M. 1993. Phytoplankton succession and diversity in a warm monomictic, relatively shallow lake: Lake Volvi, Macedonia, Greece. Hydrobiologia, 249: 33-42.

Moustaka-Gouni, M. \& G. Nikolaidis. 1990. Phytoplankton in a warm monomictic lake - Lake Vegoritis (Greece). Arch. Hydrobiol., 119: 199-213.

Moyle, P.B., J.J. Smith, R.A. Daniels, T.L. Taylor, D.G. Price \& D.M. Baltz. 1982. Distribution and ecology of stream fishes of the Sacramento-San Joaquin drainage system. Univ. Calif. Publ. Zool., 115: 1-256.

Naselli-Flores, L. \& R. Barone. 2002. Limnology of a small, temporary water body: the Pond of Santa Rosalia (Sicily, Italy). Verh. int. Ver. Limnol., 28: 1673-1677.

Naselli-Flores, L., R. Barone \& M. Zunino. 1998. Distribution patterns of freshwater zooplankton in Sicily (Italy). Verh. int. Ver. Limnol., 26: 1973-1980.

Neale, P.J., J.F. Talling, S.I. Heaney, C.S. Reynolds \& J.W.G. Lund. 1991. Long time series from the English Lake District: Irradiance-dependent phytoplankton dynamics during the spring maximum. Limnol. Oceanogr., 36: 751760

Ocevski, B. 1966. Microbiological investigations of the Balkan Lakes Ostrovo, Petersko, Rudnik and Zazerci. Verh. int. Ver. Limnol., 16: 1519-1525.

OECD, 1982. Eutrophication of Waters. Monitoring, Assessment and Control. OECD, Paris: 154 pp.
Ortega-Mayagoitia, E., C. Rojo \& M.A. Rodrigo. 2002a. Factors masking the trophic cascade in shallow eutrophic wetlands: evidence from a microcosm study. Arch. Hydrobiol., 155: 43-63

Ortega-Mayagoitia, E., C. Rojo \& M.A. Rodrigo. 2002b. Controlling factors of phytoplankton assemblages in wetlands: an experimental approach. Hydrobiologia, 502: 177-186.

Ortiz-Casas, J.L. \& R. Peña. 1984. Applicability of the OECD eutrophication models to Spanish reservoirs. Verh. int. Ver. Limnol., 22: 1521-1535.

Padan, E. \& M. Shilo. 1969. Distribution of cyanophages in natural habitats. Verh. int. Ver. Limnol., 17: 747-751.

Pattee, E., A. Maamri \& H. Chergui. 2000. Leaf litter processing and its agents in a temporary Moroccan river. Verh. int. Ver. Limnol., 27: 3054-3057.

Peduzzi, R., R. Bachofen \& M. Tonolla (Eds). 1998. Lake Cadagno: a meromictic Alpine lake. Documenta Ist. ital. Idrobiol., 63: 1-152.

Peters, R.H. 1985. Seasonal and trophic effects on size structure of the planktonic communities in four lakes of Northern Italy. Mem. Ist. ital. Idrobiol., 43: 91-104.

Petrović, G. 1975. Chemische Untersuchungen des Wassers und der Sedimente im Skutari-See. Verh. int. Ver. Limnol., 19: 1326-1332.

Pevalek, I. 1935. Der Travertin und die Plitvice Seen. Verh. int. Ver. Limnol., 7: 165-181.

Piontelli, R. \& V. Tonolli. 1964. Il tempo di residenza delle acque lacustri in relazione ai fenomeni di arricchimento in sostanze immesse, con particolare riguardo al Lago Maggiore. Mem. Ist. ital. Idrobiol., 17: 247-266.

Pirocchi, L. 1947. Struttura \& vicenda delle biocenosi mesoplanctiche del Lago Maggiore. Mem. Ist. ital. Idrobiol., 3: 57-119.

Planas, M.D. 1973. Composición, ciclo y productividad del fitoplancton del lago de Banyoles. Oecol. Aquat., 1: 3-106.

Prat, N. \& N. Bonada (Eds) 2002. El proyecto GUADALMED. Limnetica, 21: 1-204.

Prat, N. \& M. Rieradevall. 1995. Life cycle and production of Chironomidae (Diptera) from Lake Banyoles (NE Spain). Freshwat. Biol., 33: 511-524.

Prat, N. \& J.J. Ward. 1994. The tamed river. In: Margalef, R. (Ed.), Limnology now: A Paradigm of Planetary Problems. Elsevier, Amsterdam: 219-236.

Prat, N., M.A. Puig, G. González, M.J. Tort \& M. Estrada. 1984.. The Llobregat. In: Whitton, B.A. (Ed.), The Ecology of European Rivers. Blackwell Scientific Publications, Oxford: 527-552.

Pugnetti, A., P. Viaroli \& I. Ferrari. 1992. Processes leading to distrophy in a Po River Delta lagoon (Sacca Di Goro): phytoplankton-macroalgae interactions. Sci. Tot. Environm., Supplement 1992: 445-456.

Ramón, G., A. Barón, M.I. Fernández, M.F. Massanet, M. Tur, M. Vicens \& A. Vidal. 1994. Fonts de l'Almadrava (Pollença), an unusual spring site on the island of Mallorca. Verh. int. Ver. Limnol., 25: 1452-1454.

Ramos, R., F. Flores, C. Trapp, O. Siebeck \& L. Zúñiga. 1998. Thermal, light and oxygen characteristics in a small eutrophic warm monomictic lake (El Plateado, Valparaíso, Chile). Verh. int. Ver. Limnol., 26: 256-260.

Ravera, O. 1954. La struttura demografica dei Copepodi del Lago Maggiore. Mem. Ist. ital. Idrobiol., 8: 109-150.

Resh, V.H., J.K. Jackson \& E.P. McElravy. 1990. Disturbance, annual variability, and lotic benthos: example from a California stream influenced by a Mediterranean climate. Mem. Ist. ital. Idrobiol., 47: 309-330.

Reynolds, C.S., A.E. Irish \& J.A: Elliott. 2001. The ecological basis for simulating phytoplankton responses to environmental change (PROTECH). Ecol. Modell. 140: 271-291. 
Riera, J.L., J.J. Magnuson, T.K. Kratz \& K.E. Webster. 2000. A geomorphic template for the analysis of lake districts applied to the Northern Highland Lake District, Wisconsin, U.S.A. Freshwat. Biol., 43: 301-318.

Robertson, A.I., M.R. Healey \& A.J.King. 1997. Experimental manipulations of the biomass of introduced carp (Cyprinus carpio) in billabongs. II. Impacts on benthic properties and processes. Mar. Freshwat. Res., 48: 445-454.

Robertson, A.I., S.E. Bunn, P.I. Boon \& K.F. Walker. 1999. Sources, sinks and transformations of organic carbon in Australian floodplain rivers. Mar. Freshwat. Res., 50: 813829

Rodrigues-Capitulo, A., A. España, C. Ibáñez \& N. Prat. 1994. Limnology of natural wells in the Ebro Delta (NE Spain). Verh. int. Ver. Limnol., 25: 1430-1433.

Romaní, A.M., A. Giorgi, V. Acuña \& S. Sabater. 2004. The influence of substratum type and nutrient supply on biofilm organic matter utilization in streams. Limnol. Oceanogr., 49: 1713-1721.

Ros, J.D. 1991. Ramón Margalef, limnologist, marine biologist, ecologist, naturalist. Oecol. Aquat., 10: 413-423.

Rossi, V., G. Benassi, M. Veneri, C. Bellavere, P. Menozzi, A. Moroni \& K.G. McKenzie. 2003. Ostracoda of the Italian ricefields thirty years on: new synthesis and hypothesis. $J$. Limnol., 62: 1-8.

Rzóska J. \& J.F. Talling (Eds). 1976. The Nile: Biology of an ancient River. Dr. W. Junk Publishers, Amsterdam: 417 pp.

Ruggiu, D., G. Morabito, P. Panzani \& A. Pugnetti. 1998a. Trends and relations among basic phytoplankton characteristics in the course of the long-term oligotrophication of Lake Maggiore (Italy). Hydrobiologia, 369/370: 243-257.

Ruggiu, D., A. Luglié, A. Cattaneo \& P. Panzani. 1998b. Paleoecological evidence for diatom response to metal pollution in Lake Orta (N. Italy). J. Paleolimnol., 20: 333345

Saad, M.A.H. 1978. Distribution of phosphate, nitrite and silicate in Lake Edku, Egypt. Verh. int. Ver. Limnol., 20: $1124-1130$

Saad, M.A.H. \& E.I. Hemeda. 2001. Limnological characteristics of Lake Qarun, a shallow basin receiving large amounts of contaminated drainage waters. Verh. int. Ver. Limnol., 27: 3608-3612.

Sabater, S., A. Butturini, J.C. Clement, T. Burt, D. Dowrick, M. Hefting, V. Maître, G. Pinay, C. Postolache, M. Rzepecki \& F. Sabater. 2003. Nitrogen removal by riparian buffers along a European climatic gradient: Patterns and factors of variation. Ecosystems, 6: 20-30.

Salmaso, N., G. Morabito, R. Mosello, L. Garibaldi, M. Simona, F. Buzzi \& D. Ruggiu. 2003. A synoptic study of phytoplankton in the deep lakes south of the Alps (lakes Garda, Iseo, Como, Lugano and Maggiore). J. Limnol., 61: 207-227.

Scheffer, M. 1998. The Ecology of Shallow Lakes. Chapman \& Hall, London: $357 \mathrm{pp}$.

Schmidt, R., J. Müller, R. Drescher-Schneider, R. Krisai, K. Szeroczynska \& A. Baric. 2000. Changes in lake level \& trophy at Lake Vrana, a large karstic lake on the Island of Cres (Croatia), with respect to palaeoclimate and anthropogenic impacts during the last approx. 16,000 years. J. Limnol., 59: 113-130.

Sciascia, L. 1983. Cruciverba. Giulio Einaudi Editore, Torino: 359 pp.

Sechi, N. \& R. Mosello. 1985. Nutrient budget and trophic level of L. Oschiri (Sardinia, Italy). Mem. Ist. ital. Idrobiol., 43: 55-75.

Serruya, C. (Ed.) 1978. Lake Kinneret. Monographiae Biologicae, 32. Dr. W. Junk Publishers, Amsterdam: 501 pp.

Serruya, C. \& U. Pollingher. 1983. Lakes of the Warm Belt. Cambridge University Press, New York: 569 pp.
Snowden, F. 1999. Fields of death: Malaria in Italy 18611962. Modern Italy, 4: 25-57.

Sommer, B. \& P. Horwitz. 2001. Water quality and macroinvertebrate response to acidification following intensified summer droughts in a Western Australian wetland. Mar. Freshwat. Res., 52: 1015-1021.

Sommer, U., Z.M. Gliwicz, W. Lampert \& A. Duncan. 1986. The PEG-model of seasonal succession of planktonic events in fresh waters. Arch. Hydrobiol., 106: 433-471.

Soria, J.M. \& M.T. Alfonso. 1993. Relations between physicochemical and biological characteristics in some coastal intradune ponds near Valencia (Spain). Verh. int. Ver. Limnol., 25: 1009-1014.

Stanković, S. 1931. Sur les particularités limnologiques des lacs égéens. Verh. int. Ver. Limnol., 5: 158-196.

Stanković, S. 1951. Le peuplement benthique des lacs Égéens. Verh. int. Ver. Limnol., 11: 367-382.

Stanković, S. 1955. The speciation problem. Sur la spéciation dans le lac d'Ohrid. Verh. int. Ver. Limnol., 12: 478-506.

Stanković, S. 1958. Limnologie des lacs karstiques. Verh. int. Ver. Limnol., 13: 422-435.

Stanković, S. 1960. The Balkan Lake Ohrid and its living World. Dr. W. Junk Publishers, Den Haag: 357 pp.

Straskraba, M. \& J. Tundisi (Eds). 1999. Lake Biwa, Japan. Reservoir Water Quality Management (1999). UNEP/ ILEC Guidelines of Lake Management series, Vol. 9: 229 $\mathrm{pp}$.

Suárez, L. \& R. Vidal-Abarca. 2000. Metabolism of a semiarid stream of south-east Spain. Verh. int. Ver. Limnol., 27: 756-761.

Systematique des Organismes des Eaux Continentales Françaises (1981-1993). Fasc. 1-10. Bull. mens. Soc. linn. Lyon, 50: 279-304, 51: 105-304, 52: 107-135, 52: 319357, 53: 72-145, 54: 250-294, 55: 201-224, 55: 1-37, 57: 75-135, 62: 101-132.

Tafas, T.P. \& A. Economou-Amilli. 1991. Evaluation of the phytoplankton variation in Lake Trichonis (Greece) by means of multivariate analysis. Mem. Ist. ital. Idrobiol., 48: 99-112.

Talling, J.F. 1993. Comparative seasonal changes, and interannual variability and stability, in a 26-year record of total phytoplankton biomass in four English lake basins. Hydrobiologia, 268: 65-98.

Točko, M.N. 1966. La nutrition des alevins des poissons Cyprinides du lac d'Ohrid. Verh. int. Ver. Limnol., 16: 1074-1080.

Tonolli, V. \& L. Tonolli. 1951. Osservazioni sulla biologia ed ecologia di 170 popolamenti zooplanctonici di laghi italiani di alta quota. Mem. Ist. ital. Idrobiol., 6: 53-136.

Tonolli, V., L. Tonolli \& G. Bonomi. 1967. La piena circolazione in laghi oligomittici: una sottovalutata causa di contenimento della produzione zooplanctonica. Mem. Ist.ital. Idrobiol., 22: 9-52.

Valero-Garcés, B. (Ed.). 2003. Limnogeology in Spain: a Tribute to Kerry R. Kelts. CSIC. Madrid: 438 pp.

Vargas, M.J. \& A. de Sostoa. 1996. Life history of Gambusia holbrooki (Pisces, Poeciliidae) in the Ebro delta (NE Iberian Peninsula). Hydrobiologia, 341: 215-224.

Vicente, E., A. Camacho \& M.A. Rodrigo. 1993 Morphometry and physico-chemistry of the crenogenic meromictic Lake El Tobar (Spain). Verh. int. Ver. Limnol., 25: 698-702.

Vighi, M., D. Sandroni \& G. Ferri. 1995. Biomanipulation of trophic chain in two small eutrophic lakes. Mem. Ist. ital. Idrobiol., 53: 157-175.

Vila, X. \& C. Abella. 1993. Comparison of light spectral distribution in some waterbodies of Banyoles area. Verh. int. Ver. Limnol., 25: 100-104.

Vitousek, P.M., J.D. Aber, R.W. Howarth, G.E. Likens, P.A Matson, D.W. Schindler, W.H. Schlesinger \& D.G. 
Tilman. 1997. Human alteration of the global nitrogen cycle: causes and consequences. Ecol. Appl., 7: 737-750.

Vollenweider, R.A. 1956. Das Strahlungsklima des Lago Maggiore und seine Bedeutung für die Photosynthese des Phytoplanktons. Mem. Ist. ital. Idrobiol., 9: 293-362.

Vollenweider, R.A. 1963. Studi sulla situazione attuale del regime chimico \& biologico del Lago d'Orta. Mem. Ist ital. Idrobiol., 16: 21-125.

VV.AA. 1989. Lago Maggiore. Mem. Ist. ital. Idrobiol., 46: $324 \mathrm{pp}$.

Warner, R.E. \& K.M. Hendrix (Eds). 1984. Californian Riparian Systems. University of California Press, Berkeley: $1035 \mathrm{pp}$.

Webster, I.T., P.W. Ford \& G. Hancock. 2001. Phosphorus dynamics in Australian lowland rivers. Mar. Freshwat. Res., 52: 127-137.

Wynne, D. \& R. Parparova. 2002. Pollution of the Kinneret ecosystem 1980-1999: present consideration and future prospects. Verh. int. Ver. Limnol., 28: 1709-1712.

Zohary, T. 2004. Changes to the phytoplankton assemblage of Lake Kinneret after decades of a predictable, repetitive pattern. Freshwat. Biol., 49: 1355-1371.

EU Projects dealing (at least partly) with Mediterranean limnology, searchable through www.cordis.lu

AL:PE: Acidification of remote mountain lakes. Project Coordinator: Richard W. Battarbee (Univ. London, UK). Ref. STEP-0079.

AQEM: Development and testing of an integrated assessment system for the ecological quality of streams and rivers throughout Europe using benthic macroinvertebrates. Project Coordinator: Ottomar Fichtel (Univ. Essen, Germany). Ref. EVK1-CT-1999-00027.

AQUACON: Environmental chemicals: Soil - water and waste, 1992-1994. Project Coordinator: G. Facchetti (Joint Research Centre, Ispra, Italy). Ref. JRC-ENVPROT 6C003 .

BIOFILMS: Natural biofilms as high-tech conditioners for drinking water. Project Coordinator: Wim Admiraal (Univ. Amsterdam, The Netherlands). Ref EVK1CT1999-00001.

BIOMAN: Biodiversity and human impact on shallow lakes. Project Coordinator: Luc de Meester (Univ. Lovaina, Belgium). Ref. EVK2-1999-CT-00046.

ECOFRAME: Ecological quality and functioning of shallow lake ecosystems with respect to the needs of the European Water Framework Directive. Project Coordinator: Brian Moss (Univ. Liverpool, UK). Ref. EVK1-CT-1999-00039.

ERAS: Extension (Fire) retardant application and simulation. Project Coordinator: Claude Picard (CEREN, Aix-en Provence, France). Ref. EVG1-2002-00019.

Received: January 2005

Accepted: March 2005
EUREED I: Effects of interaction between eutrophication and major environmental factors on the ecosystem stability of reed vegetation in European land-water ecotones. Project Coordinator: Wilhelmus van der Putten (Netherlands Institute of Ecology, Heteren, The Netherlands). Ref. ENV1C-EV5V0083.

EUREED II: Dynamics and stability of reed-dominated ecosystems in relation to major environmental factors that are subject to global and regional anthropogenically induced changes. Project Coordinator: Hans Brix (Univ. Aarhus, Denmark). Ref. ENV2C-4-950147.

EUROLIMPACS: Integrated project to evaluate impacts of global change on European freshwater ecosystems. Project Coordinator: Simon Patrick (Univ. London, UK). Ref. GOCE-CT-2003-505540.

FIRELAB: EU Mediterranean fire laboratory. Project Coordinator: Jean-Charles Valette (INRA, Avignon, France). Ref. EVR1-2002-40028.

MOLAR: Measuring and modelling the dynamic response of remote mountain lake ecosystems to environmental change. A programme of mountain lake research. Project Coordinator: Richard W. Battarbee (Univ. London, UK). Ref. ENV2C495-0007.

NICOLAS: Nitrogen control by landscapes structures in agricultural landscapes. Project Coordinator: Gilles Pinay (Univ. Rennes, France). Ref. ENV4-CT97-0395.

PALICLAS: Palaeoenvironmental analysis of Italian crater lake sediments. Project Coordinator: F. Oldfield (Univ. Liverpool, UK). Ref. CIPD-94-0116.

STAR: Standardisation of river classifications: framework method for calibrating different biological survey results against ecological quality classifications to be developed for the Water Framework Directive. Project Coordinator: Philip Williams (Centre for Ecology and Hydrology, Dorset, UK). Ref. EVK1-CT-2001-00089.

STREAMES: Human effects on nutrient cycling in fluvial ecosystems: development of an expert system to assess stream water quality management at reach scale. Project Coordinator: Joaquim Azcón (Univ. Barcelona, Spain). Ref. EVK1-CT-2000-00081.

SWALE: Shallow wetland lake functioning and restoration in a changing European environment. Project Coordinator: Brian Moss (Univ. Liverpool, UK). Ref. ENV2C-4970420.

TEMPQSIM: Evaluation and improvement of water quality models for application to temporary waters in Southern European catchments. Project Coordinator: Henning Howind (Univ. Hannover, Germany). Ref. EVK1-CT2002-00112. 